\title{
Millennial-scale climate variability in the subpolar North Atlantic Ocean during the late Pliocene
}

\author{
Clara T. Bolton, ${ }^{1,2}$ Paul A. Wilson, ${ }^{1}$ Ian Bailey, ${ }^{1}$ Oliver Friedrich, ${ }^{1,3}$ Christopher J. Beer, ${ }^{1}$ \\ Julia Becker, ${ }^{4}$ Soma Baranwal, ${ }^{1,5}$ and Ralf Schiebel ${ }^{1,6}$ \\ Received 22 February 2010; revised 25 June 2010; accepted 21 September 2010; published 4 December 2010.
}

[1] Large-amplitude millennial-scale climate oscillations have been identified in late Pleistocene climate archives from around the world. These oscillations appear to be of larger amplitude during times of enlarged ice sheets. This observation suggests the existence of a relationship between large-amplitude millennial variations in climate and extreme glacial conditions and therefore that the emergence of millennial-scale climate variability may be linked to the Pliocene intensification of northern hemisphere glaciation (iNHG). Here we test this hypothesis using new late Pliocene high-resolution ( 400 year) records of ice-rafted debris deposition and stable isotopes in planktic foraminiferal calcite (Globigerinoides ruber) generated from Integrated Ocean Drilling Program Site U1313 in the subpolar North Atlantic (a reoccupation of the classic Deep Sea Drilling Project Site 607). Our records span marine oxygen isotope stages (MIS) $103-95$ ( 2600 to $2400 \mathrm{ka})$, the first interval during iNHG ( 3.5 to $2.5 \mathrm{Ma})$ in which large-amplitude glacial-interglacial cycles and inferred sea level changes occur. Our records reveal small-amplitude variability at periodicities of $\sim 1.8$ to $6.2 \mathrm{kyr}$ that prevails regardless of (inter)glacial state with no significant amplification during the glacials MIS 100, 98, and 96. These findings imply that the threshold for the amplification of such variability to the proportions seen in the marine archive of the last glacial was not crossed during the late Pliocene and, in view of all available data, likely not until the MidPleistocene Transition.

Citation: Bolton, C. T., P. A. Wilson, I. Bailey, O. Friedrich, C. J. Beer, J. Becker, S. Baranwal, and R. Schiebel (2010), Millennial-scale climate variability in the subpolar North Atlantic Ocean during the late Pliocene, Paleoceanography, 25, PA4218, doi:10.1029/2010PA001951.

\section{Introduction}

[2] Suborbital-scale climate instabilities $\left(10^{3}-10^{4}\right.$ years $)$ are a prominent feature of the extreme glaciations of the late Pleistocene. One of the first clues that these glacials were characterized by large-amplitude, abrupt shifts in global climate came from the recognition of a series of rapid cooling and abrupt warming events in the Greenland ice core $\delta^{18} \mathrm{O}$ records; named Dansgaard-Oeschger(D-O) events [Langway et al., 1985; Johnsen et al., 1992; Dansgaard et al., 1993; Grootes et al., 1993]. D-O events reoccur on $\sim 1.5$ kyr timescales or multiples thereof [Schulz, 2002; Rahmstorf, 2003]. During the last glacial, D-O events have been shown to be broadly synchronous [Bond and Lotti, 1995] with sea surface

\footnotetext{
${ }^{1}$ National Oceanography Centre, Southampton, School of Ocean and Earth Science, University of Southampton, Southampton, UK.

${ }^{2}$ Now at Department of Geology, University of Oviedo, Oviedo, Spain.

${ }^{3}$ Now at Facheinheit Paläontologie, Institut für Geowissenschaften, Frankfurt, Germany. UK.

${ }^{4}$ School of Ocean and Earth Sciences, University of Cardiff, Cardiff,

${ }^{5}$ Now at Geological Survey of Norway, Trondheim, Norway.

${ }^{6}$ Now at Laboratoire des Bio-Indicateurs Actuels et Fossiles, Université d'Angers 2, Angers, France.

Copyright 2010 by the American Geophysical Union. 0883-8305/10/2010PA001951
}

temperature (SST) fluctuations of $\sim 3$ to $8^{\circ} \mathrm{C}$ [Bond et al., 1993; McManus et al., 1999; Calvo et al., 2001; de Abreu et al., 2003], iceberg discharges and ice-rafted debris (IRD) deposition in the subpolar North Atlantic Ocean [Heinrich, 1988; Bond et al., 1992; Broecker et al., 1992; Bond et al., 1993; Oppo et al., 1998; Bond et al., 1999; McManus et al., 1999; Hemming, 2004; Marshall and Koutnik, 2006], as well as climate instabilities further afield [Voelker and Workshop Participants, 2002; Rohling et al., 2009]. Mechanisms proposed for large-amplitude climate change on suborbital timescales (i.e., timescales shorter than the highest Milankovitch frequency, $<19 \mathrm{kyr}$ ) are numerous [Alley et al., 1999; Clark et al., 1999; McManus et al., 1999; Wara et al., 2000; Mc Intyre et al., 2001; Weirauch et al., 2008; Meyers and Hinnov, 2010]; however, it is widely hypothesized that variable freshwater input to the northern North Atlantic Ocean and Nordic Seas, the formation regions of North Atlantic Deep Water (NADW), and resultant changes in thermohaline circulation [Broecker, 1997; Ganopolski and Rahmstorf, 2001; Knutti et al., 2004; Clement and Peterson, 2008] are involved.

[3] Several studies of Pleistocene marine sediments conclude that the magnitude of suborbital-scale climate variability is a positive function of ice sheet extent [Oppo et al., 1998; Raymo et al., 1998; McManus et al., 1999; Schulz et al., 1999; Weirauch et al., 2008]. Moreover, the idea of threshold behavior of North Atlantic climate in response to 
ice sheet size has been suggested on the basis of late Pleistocene records [McManus et al., 1999], with large-amplitude suborbital variability in surface water proxies appearing to occur whenever global sea level fell below $\sim 43$ to $-53 \mathrm{~m}$ (relative to present) [Schulz et al., 1999; Bailey et al., 2010]. This hypothesis has important implications for the origin of D-O-type events because it implies that their roots may lie in the maturation of northern hemisphere ice sheets during the late Pliocene [Bartoli et al., 2006], when the magnitude of sea level fall on orbital timescales first approached that estimated for the late Pleistocene glaciations [Cronin et al., 1994; Dwyer et al., 1995; Naish, 1997; Miller et al., 2005; Bintanja and van de Wal, 2008; Naish and Wilson, 2009; Sosdian and Rosenthal, 2009; Lourens et al., 2010; Siddall et al., 2010].

[4] A number of studies have uncovered proxy evidence of millennial-scale climate variability prior to and during the intensification of northern hemisphere glaciation (iNHG) during the Pliocene [Mc Intyre et al., 2001; Draut et al., 2003; Becker et al., 2005; Bartoli et al., 2006; Becker et al., 2006; Bailey et al., 2010; Weber et al., 2010]. However, until now no continuous suborbital-resolution records exist spanning glacial marine oxygen isotope stages (MIS) 100, 98 and 96, which represent the oldest series of glaciations over the past 3 My during which eustatic sea level fall has been reported by many to have persistently surpassed $-50 \mathrm{~m}$ (relative to modern) [Cronin et al., 1994; Dwyer et al., 1995; Naish, 1997; Miller et al., 2005; Bintanja and van de Wal, 2008; Naish and Wilson, 2009; Sosdian and Rosenthal, 2009; Lourens et al., 2010]. Here we present new records from Integrated Ocean Drilling Program (IODP) Site U1313 $\left(\sim 40^{\circ} \mathrm{N}\right)$, the only North Atlantic late Pliocene sequence with continuous coverage (at least to glacial-interglacial level) to have been recovered by advanced piston coring. We address the following hypotheses: (1) The amplitude of millennialscale surface water instability is a function of (inter)glacial state. (2) Large-amplitude millennial-scale climate oscillations only occur once an inferred ice volume threshold is crossed.

\section{Site Description}

[5] IODP Site U1313 constitutes a reoccupation of Deep Sea Drilling Program (DSDP) Site 607, originally drilled during Leg 94 [Ruddiman et al., 1987]. Together, DSDP Sites 607 and 609 (the latter reoccupied during Exp. 303 as IODP Site U1308) have proven to be benchmark sites for the study of the short- and long-term evolution of subpolar North Atlantic paleoceanography [Raymo et al., 1989; Ruddiman et al., 1989; Bond et al., 1992; Broecker et al., 1992; Raymo et al., 1992; Bond and Lotti, 1995]. In contrast to sediments from older DSDP and ODP cores, the generation of highresolution records from the reoccupied IODP sites is not compromised by the presence of coring gaps or sediment fabric disturbances resulting from the application of old drilling technology (i.e., extended core barrel techniques) [Shipboard Scientific Party, 1987, 1996]. Moreover, the identification of a hiatus at Site U1308 during MIS 100 [Bailey et al., 2010] means that Site U1313 currently presents us with a rare opportunity to construct suborbital-scale continuous records from sediments drilled by advanced piston coring in the subpolar North Atlantic during MIS 103-95.

[6] Site U1313 is located at the base of the upper western flank of the Mid-Atlantic Ridge at a water depth of $3426 \mathrm{~m}$, approximately 240 nautical miles northwest of the Azores archipelago (latitude $41^{\circ} \mathrm{N}$, longitude $32.5^{\circ} \mathrm{W}$ ) (Figure 1). Site U1313 is under the direct influence of NADW and lies on the extreme southerly limit of the "IRD belt." The IRD belt, originally defined for the last glacial cycle [Ruddiman, 1977a, 1977b], describes the southwest-northeast trending band of maximum iceberg melting and hence IRD deposition between approximately $40^{\circ} \mathrm{N}$ and $55^{\circ} \mathrm{N}$ in the Atlantic (Figure 1). Following others [e.g., McManus et al., 1999; Weirauch et al., 2008], we use planktic foraminiferal $\delta^{18} \mathrm{O}$ as a proxy for variability in surface water properties. It has been suggested that variability in surface water $\delta^{18} \mathrm{O}$ becomes progressively subdued with increasing distance from the main IRD belt [Oppo and Lehman, 1995]. Presumably this idea calls for a reduced influence of the waxing and waning of the polar front and melting icebergs on surface water $\delta^{18} \mathrm{O}$ at sites further from the IRD belt. More recently, however, large-amplitude millennial-scale fluctuations in planktic $\delta^{18} \mathrm{O}$ have been documented in the western tropical Atlantic $\left(32^{\circ} \mathrm{N}\right)$ ( $\sim 1$ to $1.5 \%$ [ Weirauch et al., 2008]), on the Iberian margin $(\sim 0.5$ to $1.5 \%$ o [de Abreu et al., 2003$])$ and at Site U1313 ( 1\%o (A. Voelker, personal communication, 2010)) during the late Pleistocene.

\section{Methods}

\subsection{Sampling}

[7] We sampled the shipboard primary splice for Site U1313 [Expedition 306 Scientists, 2006] guided by a preliminary age model [Expedition 306 Scientists, 2006] based on the correlation of shipboard-derived spectral color reflectance $\left(\mathrm{L}^{*}\right)$ to the LR04 benthic oxygen isotope stack [Lisiecki and Raymo, 2005]. Samples $(20 \mathrm{cc})$ were taken at $2 \mathrm{~cm}$ intervals from cores U1313C- $12 \mathrm{H}-4 \mathrm{~W}-0 \mathrm{~cm}$ to U1313C$13 \mathrm{H}-3 \mathrm{~W}-50 \mathrm{~cm}$ (114.12 to $123.30 \mathrm{~m}$ composite depth, $\mathrm{mcd})$. The generation of an orbital resolution ( $\sim 2 \mathrm{kyr}$ resolution) benthic oxygen isotope stratigraphy confirms that our target interval spans MIS 95 to MG1 ( 2400 to $3350 \mathrm{ka})$ (Figure 2).

\subsection{Stable Isotopes and Color Reflectance}

[8] Monospecific benthic stable isotope data were generated for MIS 95 to MG1 by analyzing specimens of Cibicidoides wuellerstorfi picked from the $>212 \mu \mathrm{m}$ sediment fraction of washed samples at $10 \mathrm{~cm}$ intervals from 114.1 to $155.3 \mathrm{mcd}$, with 2 to 8 individuals typically analyzed per sample. To characterize sea surface variability at the millennial scale during MIS 103 to 95 ( 2400 to $2600 \mathrm{ka})$, specimens of Globigerinoides ruber white (of consistent morphotype) were picked from the $212-250 \mu \mathrm{m}$ sediment fraction at $2 \mathrm{~cm}$ intervals from 114.50 to $123.28 \mathrm{mcd}$. For each sample, $30 \mathrm{G}$. ruber tests were analyzed for their oxygen and carbon isotope composition $\left(\delta^{18} \mathrm{O}_{\mathrm{pl}}\right.$ and $\left.\delta^{13} \mathrm{C}_{\mathrm{pl}}\right)$. All 


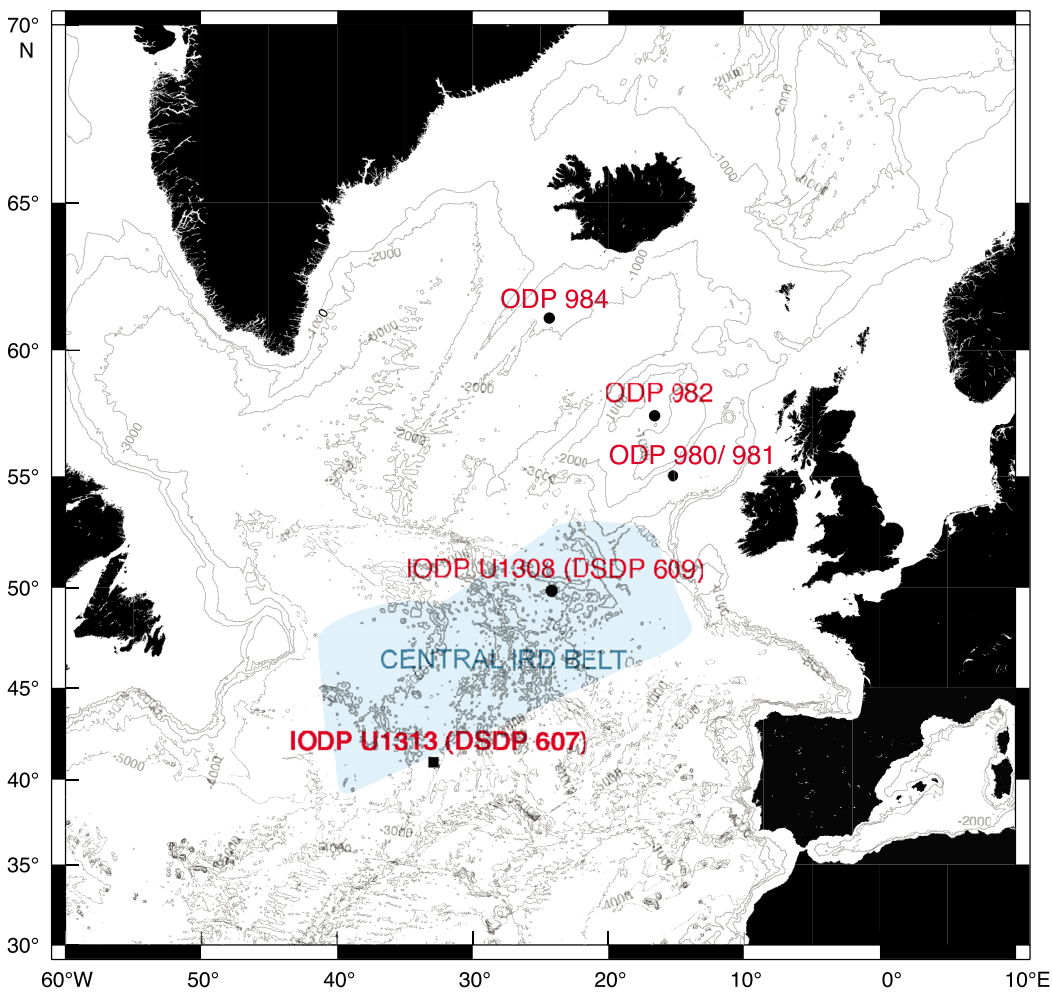

Figure 1. IODP Site U1313 [Expedition 306 Scientists, 2006] and other IODP/ODP sites discussed herein. The last glacial central North Atlantic IRD belt [Ruddiman, 1977b] is shown (blue shading) after Hemming [2004].
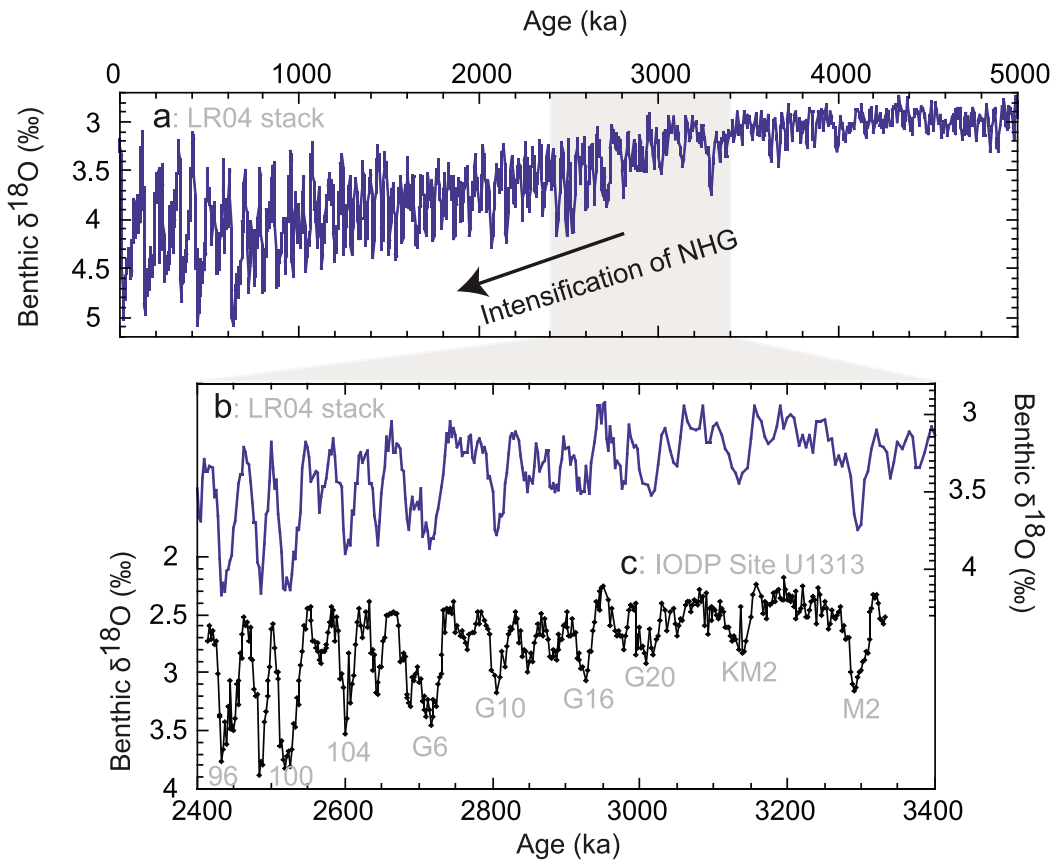

Figure 2. Our study interval in the context of Plio-Pleistocene climate as tracked by benthic $\delta^{18} \mathrm{O}$. (a) The LR04 stack for the last 5 Myr [Lisiecki and Raymo, 2005]. (b) The LR04 stack over our study interval: 3.4 to $2.4 \mathrm{Ma}$ [Lisiecki and Raymo, 2005]. (c) Cibicidoides wuellerstorfi $\delta^{18} \mathrm{O}$ values (adjusted to equilibrium; see section 3) from IODP Site U1313 spanning 3.4 to 2.4 Ma tuned to the LR04 age model. Certain glacials are named for reference. 
stable isotope measurements were performed at the University of Southampton (National Oceanography Centre) using a Europa GEO 20-20 mass spectrometer equipped with an automatic carbonate preparation system (CAPS). Results are reported relative to the Vienna Pee Dee Belemnite (VPDB) standard with an external analytical precision, based on replicate analysis of an in-house standard calibrated to NBS-19, of $0.065 \%$ for $\delta^{18} \mathrm{O}$ and $0.031 \%$ or $\delta^{13} \mathrm{C}$ (at $1 \sigma$ level). $\delta^{18} \mathrm{O}$ values of $C$. wuellerstorfi $\left(\delta^{18} \mathrm{O}_{\mathrm{cib}}\right)$ presented are adjusted for species-specific offsets from equilibrium by adding $+0.64 \%$ VPDB [Shackleton and Hall, 1984]. For MIS 103-95 we also present time series of highresolution $(2 \mathrm{~cm}$ spacing) records of the shipboard-derived light reflectance parameter L* [Expedition 306 Scientists, 2006], which has been used widely as a proxy for lithology and carbonate content [Blum, 1997; Ortiz et al., 1999].

\subsection{Ice-Rafted Debris Quantification}

[9] To examine the nature of suborbital ice rafting to our study site during MIS 103 to 95 we measured the concentration of lithic grains $>150 \mu \mathrm{m}$ per gram of dry sediment (at $2 \mathrm{~cm}$ resolution during glacial intervals and $10 \mathrm{~cm}$ resolution in between, where no IRD was present) using a standard method [e.g., Bond and Lotti, 1995] counting at least 300 grains. Following others [e.g., Jansen et al., 2000], we consider the abundance of coarse lithics to be a good firstorder proxy for the magnitude of iceberg and IRD delivery to our study site. Inspection of MIS 102 samples revealed no coarse lithic grains, a finding consistent with the smallamplitude glacial-interglacial (G-IG) change $(\sim 0.4 \%)$ in benthic $\delta^{18} \mathrm{O}$ for this glacial (Figure 2) [Lisiecki and Raymo, 2005]; therefore counts were not performed in this portion of our record. Hereafter, we refer to coarse lithics as IRD. IRD concentrations are expressed as grains gram ${ }^{-1}$ of dry sediment and as a percentage (\%) of total particles counted. Temporal variability in our IRD records is determined by cycle counting because spectral analysis cannot be confidently performed on these discontinuous records.

\subsection{Chronology}

[10] We utilize two age models in this study, based on the manual graphical correlation of our Site U1313 records using Analyseries [Paillard et al., 1996] (1) to the LR04 stack [Lisiecki and Raymo, 2005] (Figures 2 and 3b) and (2) to the benthic $\delta^{18} \mathrm{O}$ stratigraphy of ODP Site 967 in the eastern Mediterranean [Becker, 2005; Lourens et al., 2010], hereafter termed LB10 (auxiliary material Figure S1b). ${ }^{1}$ Tuning of our high-resolution records to these chronologies results in a mean temporal resolution of 394 years (LR04) and 387 years (LB10); highly comparable to and often greater than other published late Pliocene [Bartoli et al., 2006; Becker et al., 2006] and Pleistocene [McManus et al., 1999; Weirauch et al., 2008] North Atlantic records of millennial-scale climate variability.

\footnotetext{
${ }^{1}$ Auxiliary materials are available in the HTML. doi:10.1029/ 2010PA001951.
}

[11] The LR04 age model is based on tuning of stacked benthic $\delta^{18} \mathrm{O}$ records to an ice model incorporating a forcing function (21 June insolation at $65^{\circ} \mathrm{N}$ ), a nonlinearity coefficient and an ice sheet response time [Lisiecki and Raymo, 2005]. Tuning of our high-resolution Site U1313 (MIS 103-95) records to the LR04 age model results in an average linear sedimentation rate of $5.16 \mathrm{~cm} \mathrm{kyr}^{-1}$ (Figure 4). We minimize errors introduced into the chronology during tuning by inserting only one tie point at the midpoint of each climatic (G-IG) $\delta^{18} \mathrm{O}_{\text {cib }}$ transition (Figure 3). Uncertainty in the LR04 age model itself is estimated to be $6 \mathrm{kyr}$ for the interval 3 to $1 \mathrm{Ma}$ [Lisiecki and Raymo, 2005].

[12] As an alternative chronology for the interval spanning MIS 101-95, we export the LB10 timescale to Site U1313 using orbital tie points as above (Figure S1). The late Pliocene section of ODP Site 967 has been astronomically dated by tuning its Ti/Al record (a proxy for Mediterranean terrigenous input) to the precessional component of the $65^{\circ} \mathrm{N}$ summer insolation curve of solution La93 [Lourens et al., 2001, 2010]. This age model is thus independent of phase lags with respect to obliquity tuning as used in LR04. Its chronology exported to Site U1313 results in an average sedimentation rate of $5.43 \mathrm{~cm} \mathrm{kyr}^{-1}$ (Figure 4). The termination of MIS 100 is synchronous between the two age models; however, a temporal offset of $\sim 7 \mathrm{kyr}$ with respect to the onset of MIS 100 results in a longer duration for this glacial cycle when records are tuned to LR04 that to LB10. Because the LB10 age model does not cover our entire high-resolution study interval, we use LR04 for Figures 1-10 in the main body of the text, while records tuned to LB10 are shown in the auxiliary material.

[13] Regardless of the age model applied, glacial stages 100 and 96 appear characteristically sawtooth in shape with slow glacial inceptions and more rapid terminations, whereas MIS 98 is more symmetrical in shape [Lourens et al., 2010]. Age control at Site U1313 will undoubtedly be improved upon completion of a North Atlantic-wide relative paleointensity (RPI) record, one of the primary objectives of IODP Expeditions 303/306 [Channell et al., 2009].

\subsection{Sedimentation Rates, Standard Deviation, and Variance}

[14] We calculated average glacial (G) and interglacial (IG) sedimentation rates as well as mean standard deviation and variance of high-resolution records to provide a first order estimation of sedimentation rate and proxy variability versus glacial state (see Table 1 for LR04 age model and Table S1 in Text S1 for LB10 age model). G and IG conditions are defined based on $\delta^{18} \mathrm{O}_{\text {cib }}$ values. For this purpose, the durations of MIS 100, 98 and 96 are defined by the first time that $\delta^{18} \mathrm{O}_{\text {cib }}$ crosses 3.8\%o during the descent into, and ascent from, the glacial. MIS 102, a much smaller-amplitude glacial, is defined by the first time that $\delta^{18} \mathrm{O}_{\text {cib }}$ values of 3.3\% are crossed in both directions. These values approximately coincide with the midpoints of glacial inceptions and terminations (Figure $3 \mathrm{c}$ ).

[15] In the LR04 age model, average $\mathrm{G}$ sedimentation rates are slightly lower than average IG rates $\left(4.99 \mathrm{~cm} \mathrm{kyr}^{-1}\right.$ versus $5.24 \mathrm{~cm} \mathrm{kyr}^{-1}$, respectively). Mean sedimentation rates derived from tuning our records to the LB10 age model show 


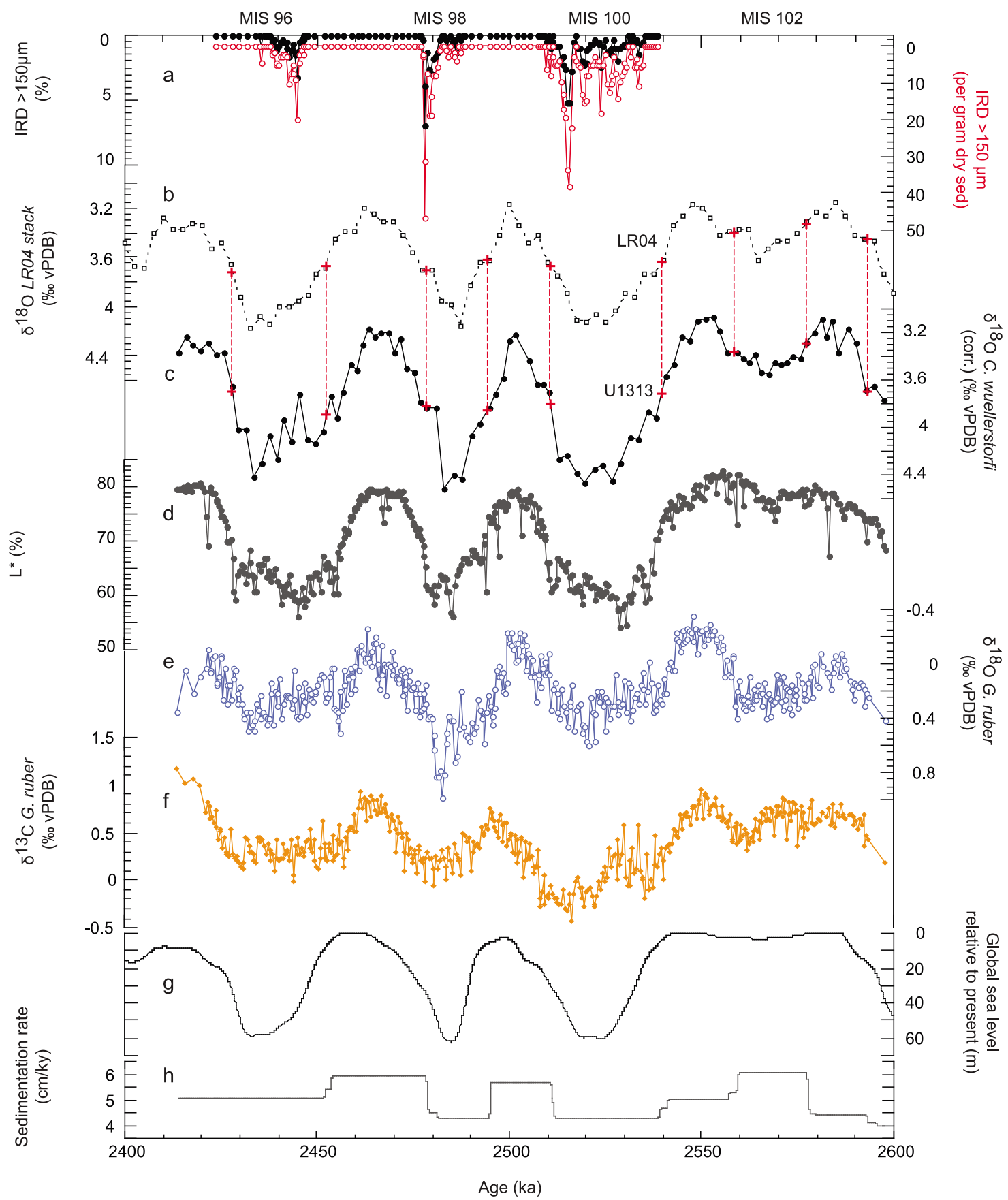

Figure 3. High-resolution proxy paleoclimate records from IODP Site U1313 (MIS 103-95) tuned to LR04 [Lisiecki and Raymo, 2005]. (a) IRD in both percent (\%) (black, left axis) and grains gram ${ }^{-1}$ dry sediment (red, right axis). Note inverted axes. (b) The LR04 stack [Lisiecki and Raymo, 2005]. (c) $\delta^{18} \mathrm{O}_{\text {cib }}$ from Site U1313 (\%, relative to VPDB), with tie points shown as red crosses with dotted lines. (d) $\mathrm{L}^{*}$ light reflectance parameter (\%) [Expedition 306 Scientists, 2006]. (e) G. ruber $\delta^{18} \mathrm{O}$ (\%o VPDB) (f) G. ruber $\delta^{13} \mathrm{C}(\%$ VPDB) (g) Modeled global sea level relative to present (m) [Bintanja and van de Wal, 2008]. (h) Average linear sedimentation rates $\left(\mathrm{cm} \mathrm{kyr}^{-1}\right)$ between tie points.

greater $\mathrm{G}$ to IG variability $\left(6.47 \mathrm{~cm} \mathrm{kyr}^{-1}\right.$ and $4.84 \mathrm{~cm} \mathrm{kyr}^{-1}$, respectively). Mean variance and standard deviation were calculated for $\mathrm{L}^{*}, \delta^{18} \mathrm{O}_{\mathrm{pl}}$ and $\delta^{13} \mathrm{C}_{\mathrm{pl}}$, as well as these same data sets notch-filtered (frequency $=0.025$, bandwidth $=$
$0.07)$ to remove the dominant obliquity period. Filtering ensures that varying rates of change associated with Milankovitch periodicities do not bias the variance and standard deviation calculated for each G or IG interval. It 


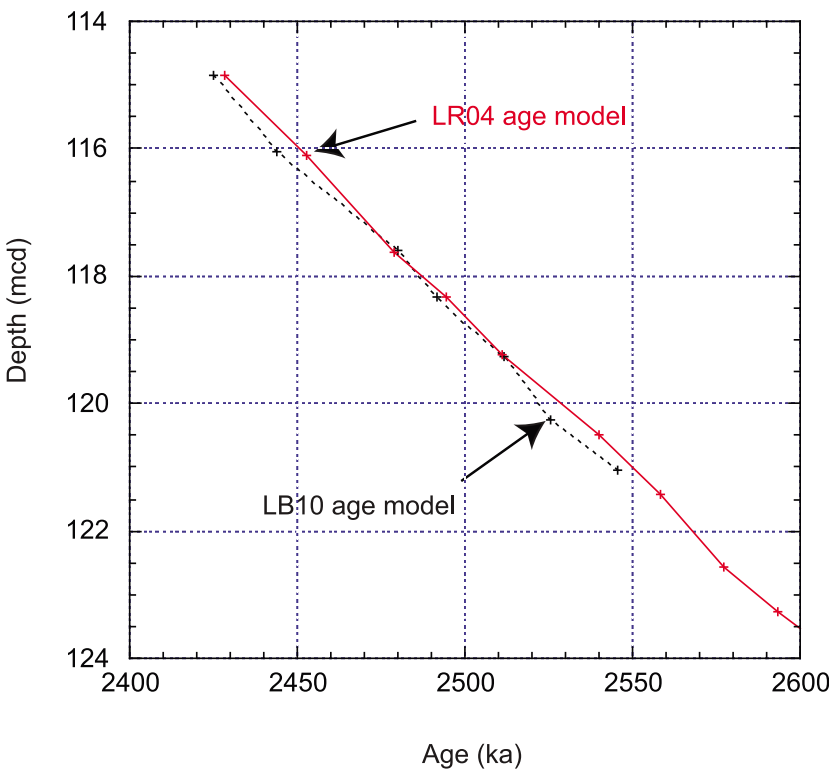

Figure 4. Age-depth plot for both of the Site U1313 age models discussed in this study.

is, however, important to note that variance and standard deviation values are influenced by the differing length and number of data points within each defined G or IG interval.

\subsection{Statistical and Spectral Analyses}

[16] Spectral analyses were carried out on $\delta^{18} \mathrm{O}_{\mathrm{pl}}, \delta^{13} \mathrm{C}_{\mathrm{pl}}$ and $\mathrm{L}^{*}$ records using the multitaper method assuming a red noise model with the SSA-MTM Toolkit software [Ghil et al., 2002]. Analyses were carried out on data sets tuned to both age models to determine whether the chosen age model affected the resultant frequency spectrum. Data series were interpolated to preserve the maximum resolution in the original data, resulting in a constant time step of $0.34 \mathrm{ka}$ (LR04 age model) and $0.28 \mathrm{ka}$ (LB10 age model). Theoretically, the Nyquist frequency (defined as $1 /[2 \times$ sampling interval]) describes the limit up to which high-frequency information can be obtained from a particular data set [Weedon, 2003]. Our LR04 and LB10 age models yield Nyquist frequencies of $1.24 \mathrm{cycles} / \mathrm{kyr}$ and $1.3 \mathrm{cycles} / \mathrm{kyr}$, respectively. It is generally argued, however, that a minimum of four data points per oscillation is required to make reliable interpretations based on cyclicity. It is unlikely that $G$. ruber isotope and $\mathrm{L}^{*}$ time series are significantly aliased, first because of the high temporal resolution relative to suborbitalscale cycles and second because each data point represents a time-integrated average of contiguous $2 \mathrm{~cm}$ sampling.

[17] We used wavelet analysis [Torrence and Compo, 1998] to assess any changes in the occurrence or significance of periodic signals in our $\delta^{18} \mathrm{O}_{\mathrm{pl}}, \delta^{13} \mathrm{C}_{\mathrm{pl}}$ and $\mathrm{L}^{*}$ time series over time. All data sets were first notch-filtered (Gaussian filter with frequency 0.025 , bandwidth 0.07 ) to remove the dominant obliquity period that affects the ability to resolve short periods, then interpolated as described above for spectral analysis. We assumed a red noise model and a $95 \%$ confidence level for nonzero coherence. All computations were carried out in MATLAB using wavelet software written by C. Torrence and G. Compo available at http://paos. colorado.edu/research/wavelets/. Wavelet analyses of raw

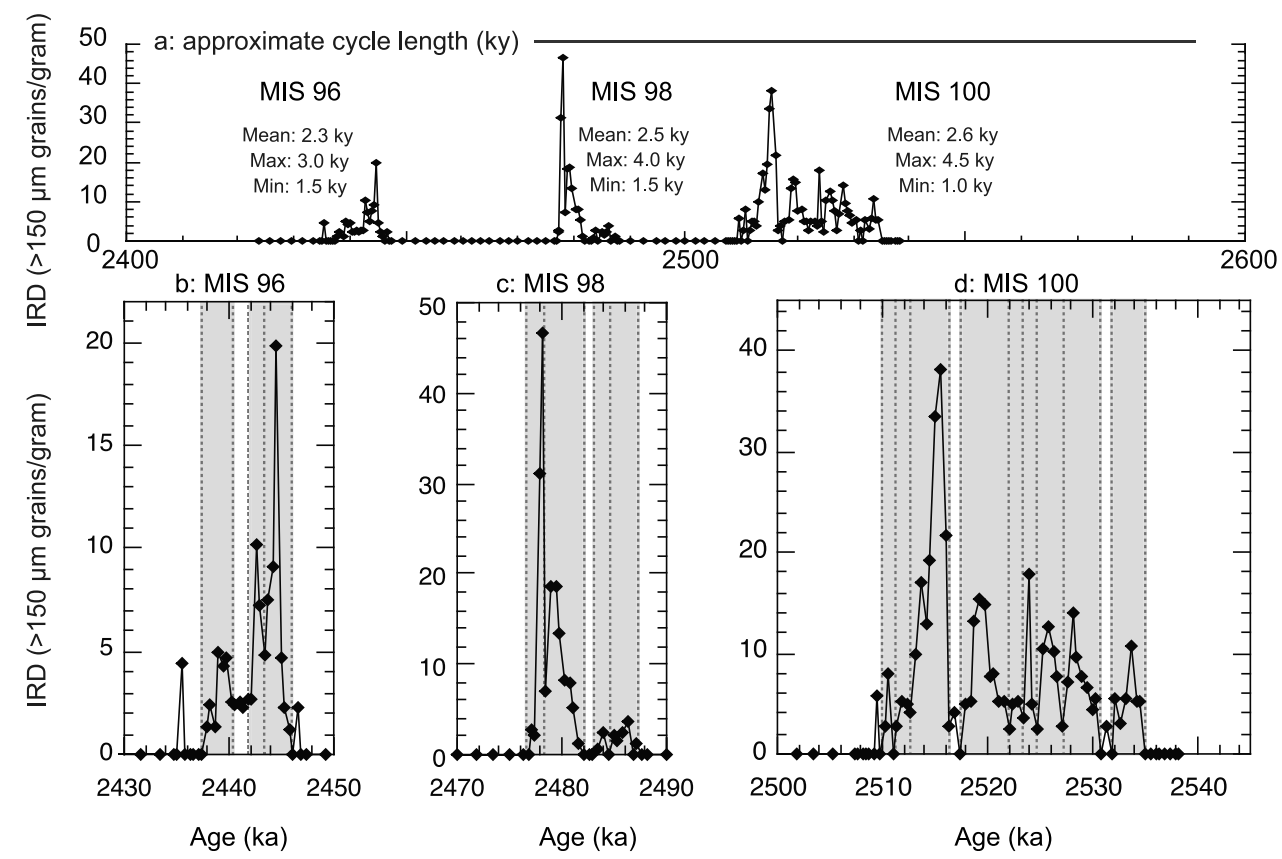

Figure 5. Visual analysis of IRD cycles tuned to LR04. (a) Mean, minimum, and maximum cycle durations are indicated for each glacial period (continuous age scale). (b-d) Vertical lines delineate IRD events in individual glacials. Note different scales on $y$ axes in Figures 5b, 5c, and 5d. 

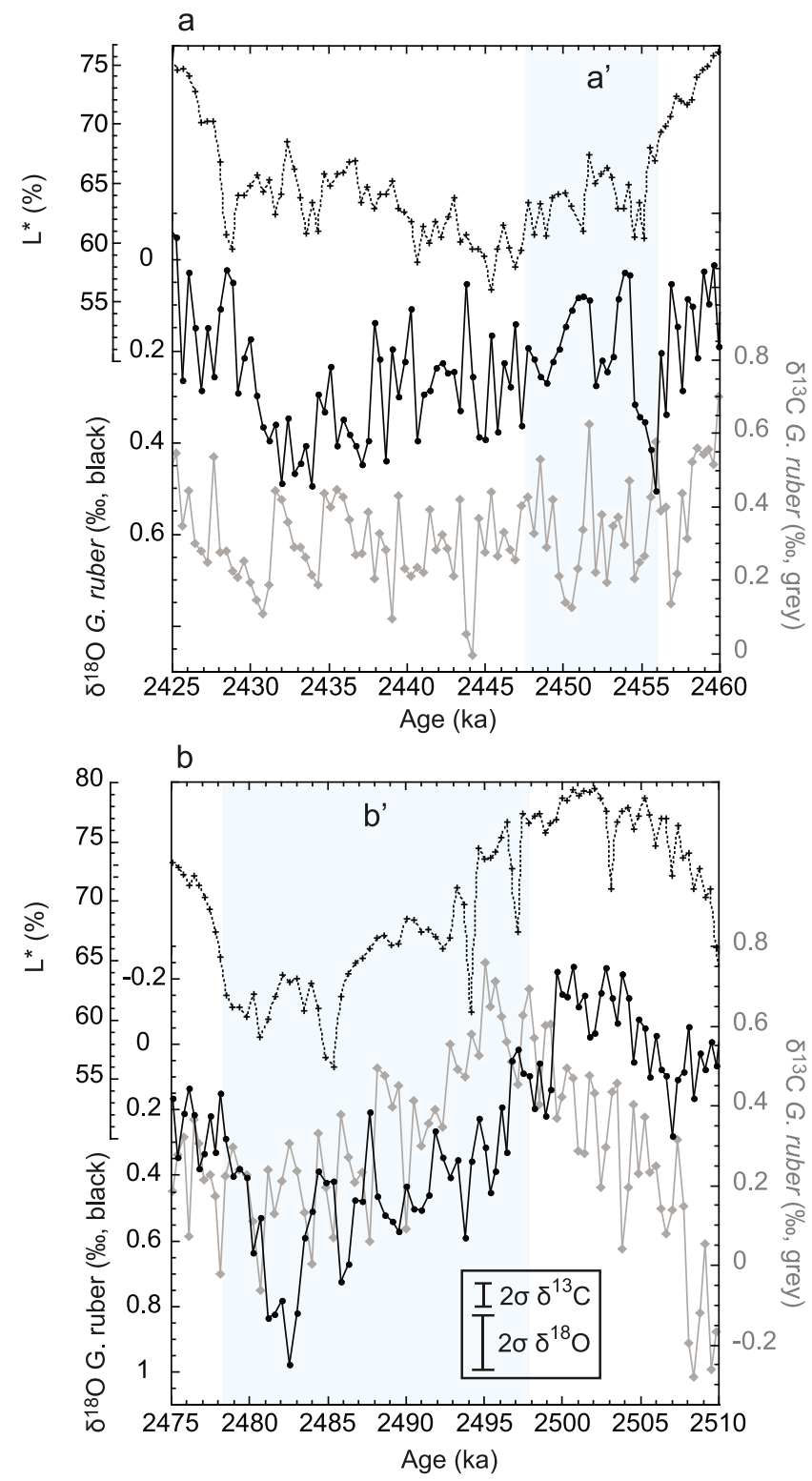

Figure 6. Two intervals in which well-defined suborbital variability is seen by eye: (a) $2425-2460 \mathrm{ka}$ (during the descent into MIS 96) and (b) 2475-2510 (during MIS 98). $\delta^{18} \mathrm{O}_{\mathrm{pl}}$ (black circles and lines), $\delta^{13} \mathrm{C}_{\mathrm{pl}}$ (gray diamonds and lines) and $\mathrm{L}^{*}$ (crosses and dotted lines) records are shown. External analytical error at the $1 \sigma$ level for $\delta^{18} \mathrm{O}( \pm 0.065 \%)$ and $\delta^{13} \mathrm{C}( \pm 0.031 \%)$ is illustrated on a scale bar. Shaded intervals a' and b' are also marked on Figure $7 \mathrm{a}$ and Figure S3a (pink circles).

data sets were carried out but are not shown because the dominance of obliquity caused all suborbital frequencies to fall below the $95 \%$ confidence level.

[18] As an alternative means of statistically distinguishing 'real' features from background sampling variability (noise) in our $\delta^{18} \mathrm{O}_{\mathrm{pl}}$ record, we use a space-scale technique named SiZer (Significant Zero crossing of derivatives). SiZer [Chaudhuri and Marron, 1999] uses a 'family of smoothing' approach in which the detection of significant features is conducted over all possible bandwidths, i.e., removing the need to prescribe a specific bandwidth over which to smooth data, a practice that can determine which features are observed and thus deemed 'real'. In this method, the statistical significance of the first and second derivatives of the family of smooths is calculated using MATLAB (P. Chaudhuri et al., An introduction to SiZer basics, http://www.unc.edu/ $\sim$ marron/DataAnalyses/SiZer_Intro.html\#redirect, accessed January 2010), allowing assessment of the significance of each feature of the smoothed records.

\section{Results}

\subsection{IRD}

[19] The composition of IRD deposited at Site U1313 during our study interval is similar to that previously reported from other late Pliocene subpolar North Atlantic sediments [Becker et al., 2006; Bailey et al., 2010], and is dominated by (haematite stained) quartz and feldspar, basaltic glass and siliciclastic rock fragments. Thus, IRD composition at Site U1313 resembles that of 'ambient IRD' described from the North Atlantic in the last glacial cycle, as opposed to "Heinrich event IRD," which also contains diagnostic detrital dolomite and limestone clasts (detrital carbonate) [Bond et al., 1992; Broecker et al., 1992; Bond and Lotti, 1995]. Concentrations of IRD during MIS 100, 98 and 96 are generally low $\left(<20\right.$ lithic grains gram ${ }^{-1}$ or $2 \%$ ), with peak values obtained during the deglacial phases of MIS 100 (38 grains gram $^{-1}$ or $5.1 \%$ ) and MIS 98 (47 grains gram ${ }^{-1}$ or $6.9 \%$ ) (Figure 3a and Figure S1a). These values are comparable to previously published orbital resolution records of late Pliocene IRD abundance at DSDP Site $607(0-2 \%>125 \mu \mathrm{m}$ between 2500 and $2800 \mathrm{ka}$ ) [Flesche Kleiven et al., 2002], and not dissimilar to those found at more northern North Atlantic sites during the Holocene [Bond et al., 1997]. Cycle counting yields ice rafting events with a mean duration of $\sim 2.5 \mathrm{kyr}$ (LR04 age model) or $\sim 1.8 \mathrm{kyr}$ (LB10 age model), recurring on average every $\sim 2.7 \mathrm{kyr}$ (LR04 age model) or $\sim 1.9 \mathrm{kyr}$ (LB10 age model) during times of IRD deposition (Figure 5 and Figure S2). This pattern of late Pliocene IRD events is consistent with the pacing of North Atlantic IRD events reported in published Plio-Pleistocene records [Bond and Lotti, 1995; Bond et al., 1997; Raymo et al., 1998; Bond et al., 1999; McManus et al., 1999; Mc Intyre et al., 2001; Becker et al., 2006].

\subsection{Suborbital Variability}

[20] High-resolution $\delta^{18} \mathrm{O}_{\mathrm{pl}}, \delta^{13} \mathrm{C}_{\mathrm{pl}}$ and $\mathrm{L}^{*}$ data are shown in Figure 3 (LR04) and Figure S1 (LB10). In Figure 6 we show two intervals of the $\delta^{18} \mathrm{O}_{\mathrm{pl}}, \delta^{13} \mathrm{C}_{\mathrm{pl}}$ and $\mathrm{L} *$ records in which suborbital cycles are clearly visible in multiple data series, are supported by a reasonable number of data points (i.e., >5), and with an amplitude greater than the range of external analytical error. Two subsections of these intervals highlighted in Figure 6 (blue shading, marked a' and b') also exhibit significant power at suborbital periods in wavelet analyses (pink circles in Figure 7a). Spectral analyses of our $\delta^{18} \mathrm{O}_{\mathrm{pl}}, \delta{ }^{13} \mathrm{C}_{\mathrm{pl}}$ and $\mathrm{L}^{*}$ records reveal significant power above the $99 \%$ confidence level (CL) at a number of suborbital 

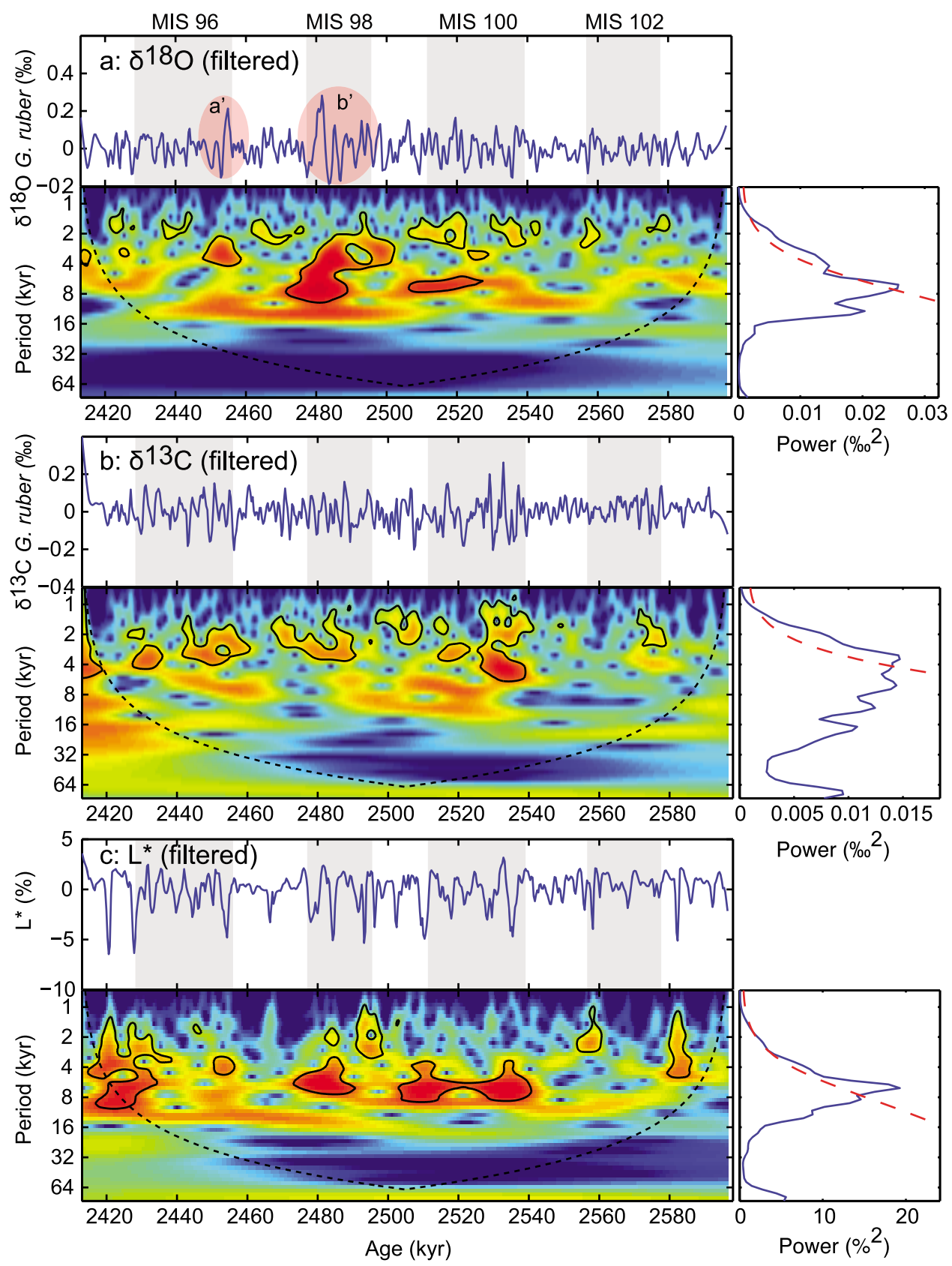

Figure 7. Wavelet analysis of (a) $\delta^{18} \mathrm{O}_{\mathrm{pl}}$, (b) $\delta^{13} \mathrm{C}_{\mathrm{pl}}$, and (c) $\mathrm{L}^{*}$ for filtered time series (Gaussian notchfiltered at frequency 0.025 and bandwidth 0.07 to remove the dominant obliquity period) tuned to the LR04 age model. In Figures 7a-7c, the filtered input data series (top), the wavelet power spectrum (bottom left), and the global wavelet spectrum (bottom right, with 95\% CL shown in red) are shown. Grey shaded intervals represent glacials (as defined in section 3.5). Black solid lines denote the $95 \%$ confidence contours. The dashed black line represents the cone of influence, below which edge effects become important and confident interpretation cannot be drawn [Torrence and Compo, 1998]. Records from pink circled intervals a' and b' in Figure $7 \mathrm{a}$ are shown in detail in Figure 6.

frequencies. Raw and filtered data sets, tuned to both age models, show similar results (Figure 8 and Figure S4). For $\delta^{18} \mathrm{O}_{\mathrm{pl}}$, suborbital frequencies above the $99 \%$ CL correspond to periodicities of 1.9 to $4.5 \mathrm{kyr}$ (LR04) or 1.4 to $4.5 \mathrm{kyr}$ (LB10). The $\delta^{13} \mathrm{C}_{\mathrm{pl}}$ record contains periodicities above the
$99 \%$ CL of 1.8 to $3.3 \mathrm{kyr}$ (LR04) or 1.7 to $4.5 \mathrm{kyr}$ (LB10). For L*, $>99 \%$ CL periodicities are between 2 and $6.2 \mathrm{kyr}$ (LR04) or 1.5 and $5.3 \mathrm{kyr}$ (LB10). To isolate the significant suborbital periodicities identified during spectral analysis of isotope records (LR04; $1.9 \mathrm{kyr}$ for $\delta^{18} \mathrm{O}$ and 1.8 to $2 \mathrm{kyr}$ for 

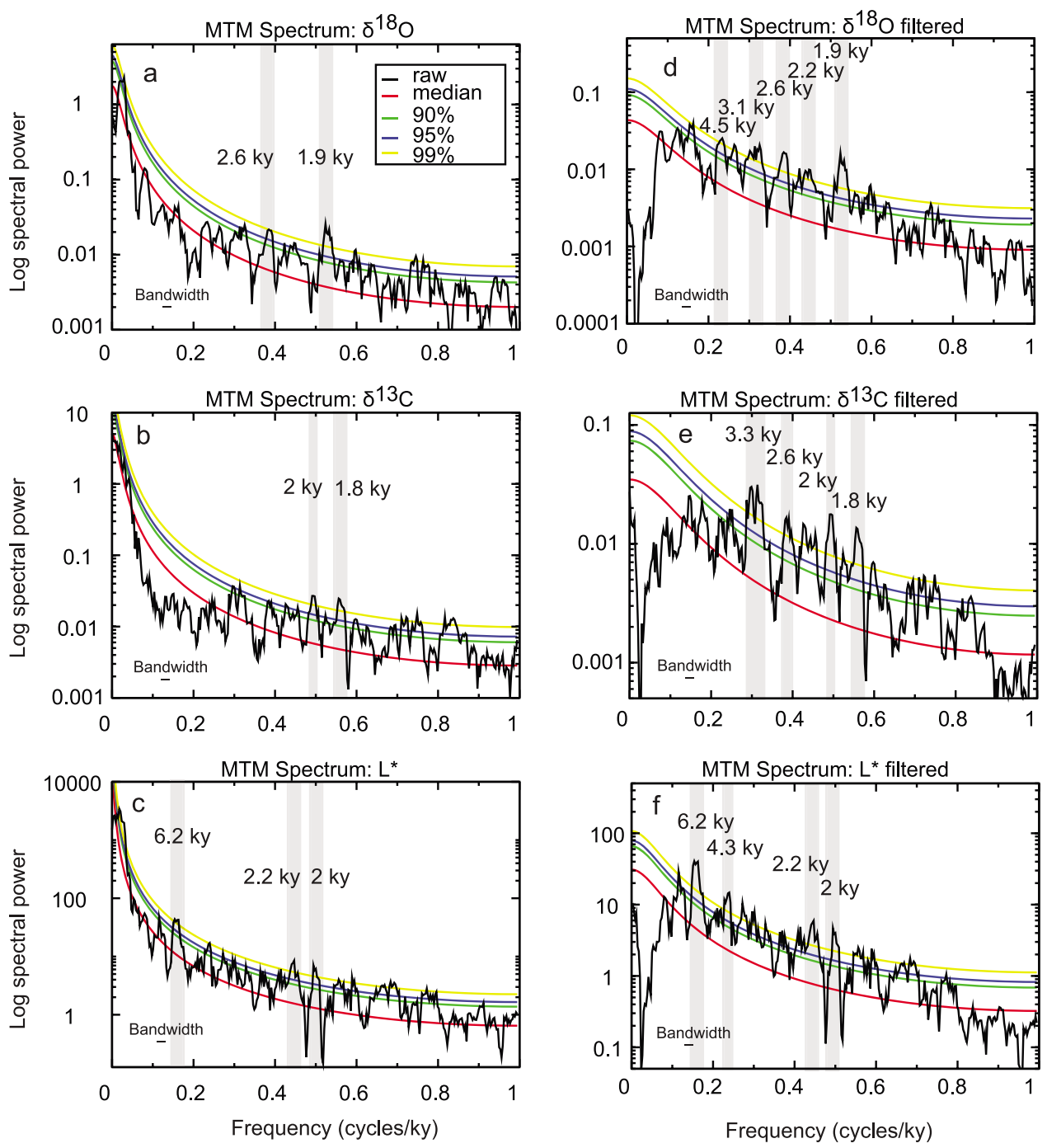

Figure 8. Spectral analyses of $\delta^{18} \mathrm{O}_{\mathrm{pl}}, \delta^{13} \mathrm{C}_{\mathrm{pl}}$, and $\mathrm{L}^{*}$ for $(\mathrm{a}-\mathrm{c})$ raw and $(\mathrm{d}-\mathrm{f})$ filtered time series (Gaussian notch-filtered at frequency 0.025 and bandwidth 0.07 to remove the dominant obliquity period) tuned to the LR04 age model. Note different log spectral power scale on all $y$ axes. Frequencies exhibiting power above the $99 \%$ confidence level are shaded.

$\delta^{13} \mathrm{C}$, Figure 8), we applied a specific Gaussian band-pass filter to each record. Variance at the $\sim 2 \mathrm{kyr}$ period appears to be a prominent feature of both isotope records, with amplitude modulation apparently unrelated to glacial state (Figure 9). Wavelet analyses of filtered $\delta^{18} \mathrm{O}_{\mathrm{pl}}, \delta^{13} \mathrm{C}_{\mathrm{pl}}$, and $\mathrm{L}^{*}$ records display variability above the $95 \%$ confidence level at suborbital frequencies between 1 and $8 \mathrm{kyr}$ (Figure 7 and S3). Patches of significant variance at suborbital frequencies occur during both $\mathrm{G}$ and IG intervals, with maximum variance centered around MIS 100-99-98 for all three records (Figures $7 \mathrm{a}-7 \mathrm{c}$ and Figures $\mathrm{S} 3 \mathrm{a}-\mathrm{S} 3 \mathrm{c}$ ), and additionally during MIS 95 for L* (Figure 7c and Figure S3c).

[21] SiZer results (Figure 10) indicate that statistical significance can only reliably be attached to the slope and curvature changes associated with G-IG cycles, as indicated by the red and blue colored areas in Figures 10b and 10c. The black (data-driven) smooth curve in Figure 10a suggests that small-amplitude suborbital-scale features are present in these data; however, the SiZer significance maps (Figures 10b and 10d) indicate that, taking into account the time resolution and number of data points, these "features" could result from natural sample fluctuations.

[22] With both age models, we document significant suborbital periodicities of between $\sim 1.8$ and $6.2 \mathrm{kyr}$ duration in Site U1313 late Pliocene climate proxy records. The pacing of suborbital variability in our records is highly comparable to that reported from planktic foraminiferal isotope records from the Holocene [Bond et al., 1997], MIS 5 [Oppo et al., 2001], the early Pleistocene and Pliocene North Atlantic [Raymo et al., 1998; Mc Intyre et al., 2001; Draut et al., 2003; Bartoli et al., 2006], and specifically for MIS 100 in both the Mediterranean and the North Atlantic [Becker et al., 2005, 2006], Additionally, records of Pliocene color reflectance from Greek lacrustine deposits [Steenbrink et al., 2003; 


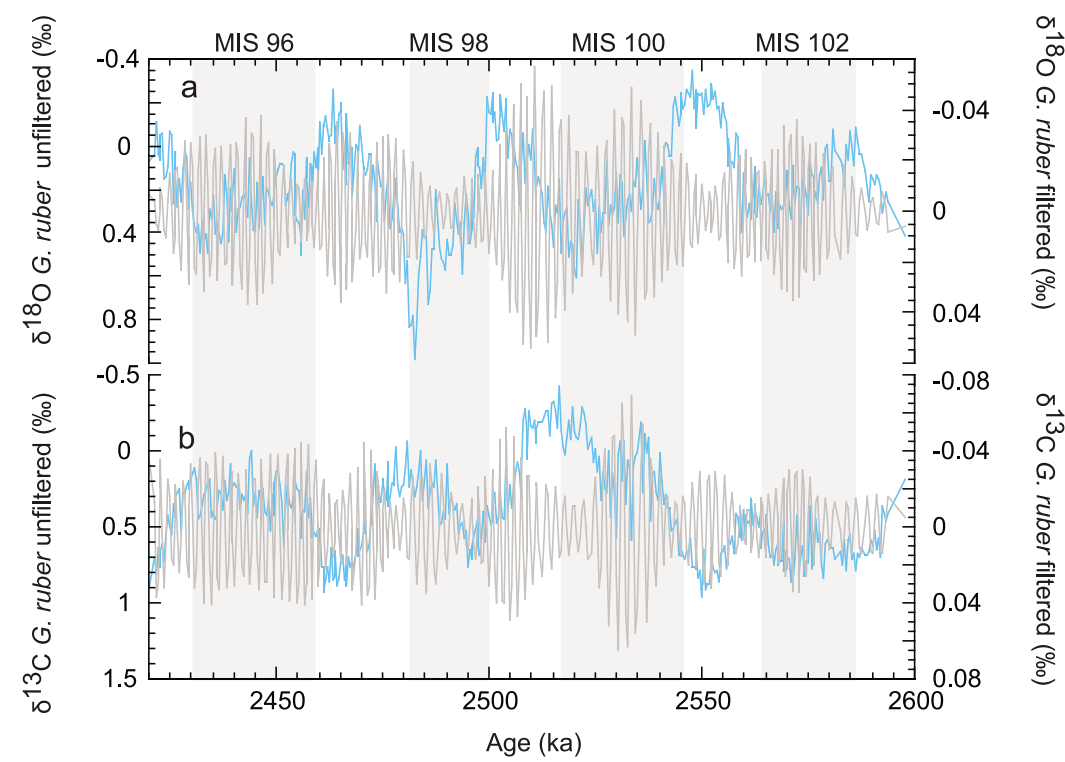

Figure 9. Gaussian band-pass-filtered G. ruber isotope records (gray lines) plotted with unfiltered isotope records (blue lines) tuned to the LR04 age model. Filter design is based on significant spectral peaks in MTM spectral analyses (Figure 8). (a) $\delta^{18} \mathrm{O}_{\mathrm{pl}}$ : frequency, 0.53 (1/1887 years); bandwidth, 0.05 (2083 to 1724 years). (b) $\delta^{13} \mathrm{C}_{\mathrm{pl}}$ : frequency, 0.50 (1/2000 years); bandwidth, 0.05 (1818 to 2222 years). Grey shaded intervals represent glacials as defined in section 3.5. Larger-amplitude modulation in filtered records is not consistently associated with glacial intervals.

Weber et al., 2010] and North Atlantic marine sediments [Ortiz et al., 1999] show similar pacing of suborbital-scale variability.

[23] Regardless of the pacing of suborbital-scale change in our data sets, it is evident that the variability in $\delta^{18} \mathrm{O}_{\mathrm{pl}}$ at Site U1313 is small in amplitude $(<0.5 \%$, Figure $3 \mathrm{e})$ relative to that recorded in late Pleistocene North Atlantic records (0.5 to $>1.5 \%$ [McManus et al., 1999; de Abreu et al., 2003; Weirauch et al., 2008]). Low values of variance and standard deviation (for $\delta^{18} \mathrm{O}_{\mathrm{pl}}$ mean $\mathrm{G}$ variance $=0.019 \%$, standard deviation $=0.14 \%$; Table 1 ) are found in the late Pliocene as compared to the late Pleistocene glacials, during which variance in $\delta^{18} \mathrm{O}_{\mathrm{pl}}$ averages $0.17 \%$ (MIS 12 to 22) [Weirauch et al., 2008]. Furthermore, our records show no evidence for threshold-type amplification during glacial conditions (Table 1 and Figures 7 and 9).

\section{Discussion}

[24] In order to explain the absence of large-amplitude suborbital change in our data sets, it is necessary to consider the factors responsible for variability in our $\delta^{18} \mathrm{O}_{\mathrm{pl}}$ record. We first discuss the result of the SiZer analysis to evaluate significance in our record (section 5.1). Subsequently, we examine the factors potentially contributing to the amplitude of change recorded in our $\delta^{18} \mathrm{O}_{\mathrm{pl}}$ record, namely sedimentation rates (section 5.2), foraminiferal ecological preferences (section 5.3) and environmental change (section 5.4).

\subsection{SiZer Analysis}

[25] To further evaluate the significance of suborbital signals in our $\delta^{18} \mathrm{O}_{\mathrm{pl}}$ record, we now consider the results of the
SiZer statistical analysis of this time series (Figure 10). This result illustrates the problems associated with resolving highfrequency variability in deep-sea sediments, where sedimentation rates in undisturbed settings (i.e., excluding drift sites) are typically between 1 and $5 \mathrm{~cm} \mathrm{kyr}^{-1}$. At these sedimentation rates, the detection and amplitude of millennialscale variations in deep-sea sediments can be significantly affected by bioturbation [Keigwin and Guilderson, 2009]. Modeling results suggest that, in cores with sedimentation rates of $\sim 10 \mathrm{~cm} \mathrm{kyr}^{-1}$, substantial attenuation of the amplitude of millennial-scale signals occurs, with $30-70 \%$ of the original signal lost depending on mixing strength [Anderson, 2001]. Visual inspection of the core intervals used in this study shipboard [Expedition 306 Scientists, 2006] and during postcruise sampling indicate that bioturbation in our study interval is rare and moderate where present. Nevertheless, considering both average sedimentation rate $\left(\sim 5 \mathrm{~cm} \mathrm{kyr}^{-1}\right)$ and sampling resolution $(2 \mathrm{~cm})$, it is likely that shorter duration millennial events have been attenuated by bioturbation to some degree and so are less well preserved relative to events of longer duration.

[26] The SiZer result at Site U1313 (i.e., statistical significance only reliably attached to G-IG changes, Figure 10) is perhaps not surprising given that application of this smoothing method to two classic Pleistocene $\delta^{18} \mathrm{O}_{\mathrm{pl}}$ records from high-sedimentation drift sites [McManus et al., 1999; Weirauch et al., 2008], both containing large-amplitude $(>1 \%$ ) millennial-scale oscillations, does not yield statistically significant millennial-scale "events" (Figure S5). These results can be understood in terms of the resolution and therefore number of data points defining suborbital cycles. 

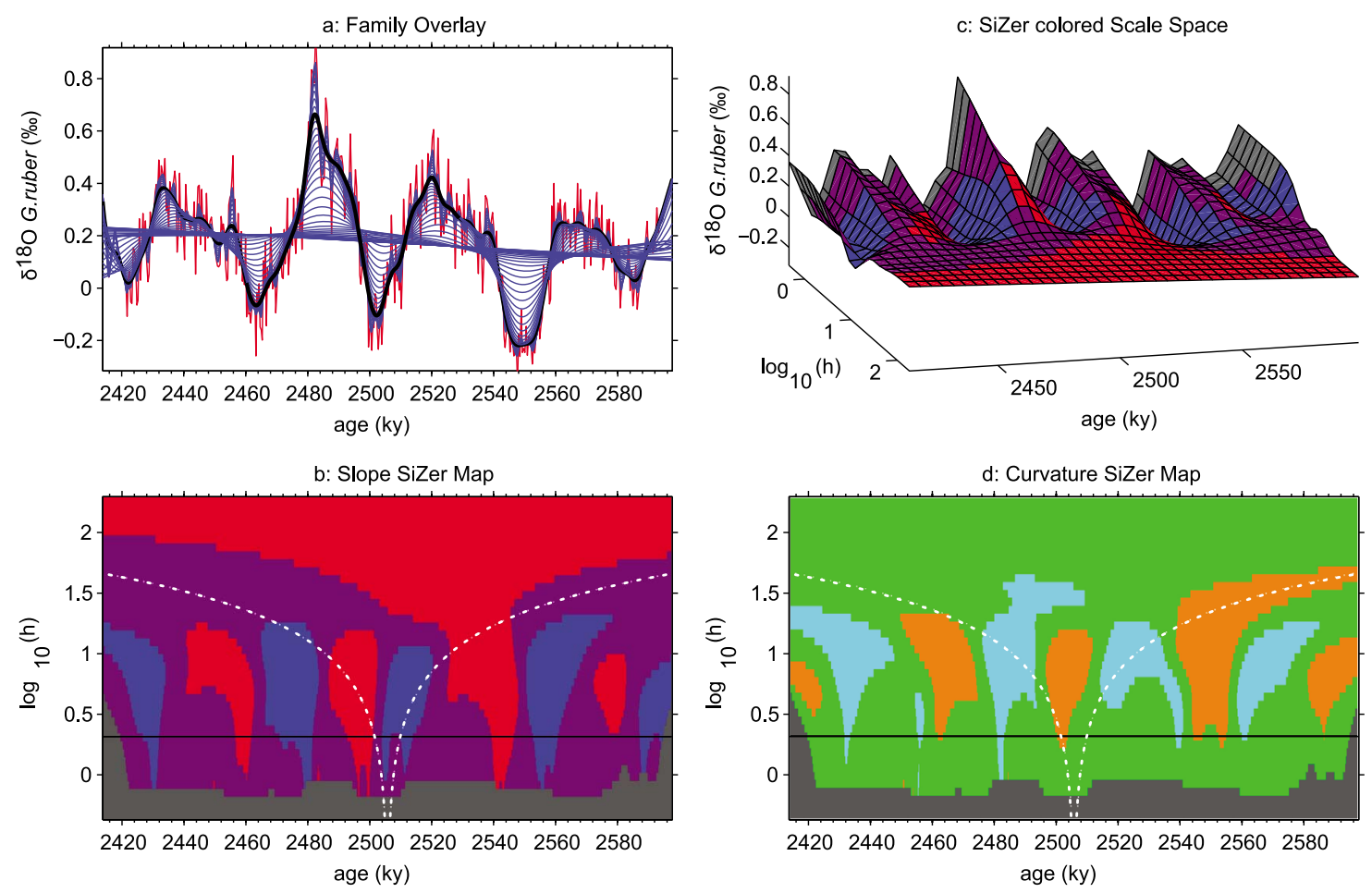

Figure 10. Results of SiZer analysis for $\delta^{18} \mathrm{O}_{\mathrm{pl}}$ tuned to the LR04 age model. 801 bins were calculated along the $x$ axis (although a reduction in bin number did not alter results) and a 95\% confidence interval was applied. (a) Family overlay plot. Raw data are shown in red, and the family of smooths is shown in blue. The black line in the family overlay plot represents the smooth calculated with the bandwidth closest to a "data-driven" choice (i.e., the most appropriate bandwidth for smoothing for the data set under consideration) and is also indicated in Figures 10b and 10d. (b) Slope SiZer Map (first derivative), indicates which increasing (blue) or decreasing (red) slopes in the smooth curves are statistically significant at given bandwidths. Purple coloring indicates that the evidence in the data is not strong enough to conclude a significant change, and gray coloring indicates that data are too sparse for meaningful inferences to be made. (c) SiZer colored scale space, a 3-D representation combining the smoothed data in Figure 10a (black line) with the first derivative significance data in Figure 10b. Color scale is the same as in Figure 10b. (d) Curvature SiZer Map (second derivative). Cyan indicates significant upward (positive) curvature, and orange indicates significant downward (negative) curvature. More smoothing is required to achieve significance here because noise is felt more strongly in the second derivative.

Attaching statistical significance to millennial-scale 'events' using SiZer is only achievable in climate records with very high temporal resolution (decadal to centennial), for example, a number of the Holocene climate proxy records compiled by Rohling and Pälike [2005].

\subsection{Sedimentation Rates}

[27] Given that a key objective of this study is to compare the amplitude of suborbital change during $\mathrm{G}$ and IG stages, a thorough understanding of $\mathrm{G}-\mathrm{IG}$ sedimentation rates is required because of the time integrating (aliasing) effect that they can impart on down core changes in the amplitude of millennial-scale variability [Weirauch et al., 2008]. However, regardless of age model or filter applied, no significant correlations are found between average sedimentation rates and average variance or standard deviation (Table 1 and Table S1 in Text S1), suggesting that the amplitude of high- frequency variance in our data sets is not controlled by changes in sedimentation rate.

\subsection{Species Choice and Potential Ecological Bias}

[28] It is possible that the ecological preference of G. ruber white for warmer temperatures (within the range $13^{\circ}$ to $32^{\circ} \mathrm{C}$ [Bijma et al., 1990; Schmidt and Mulitza, 2002]) could result in only the higher end of the glacial temperature spectrum being recorded in our record, thus artificially reducing the amplitude of suborbital change observed [Becker et al., 2006]. The mean relative abundances of $G$. ruber white at Site U1313 during glacials MIS 100, 98 and 96 (as defined in section 3.5 ), are $2.7 \%, 2.9 \%$ and $5.3 \%$, respectively, slightly lower than mean IG abundances of $7.5 \%$ and $6.4 \%$ for MIS 99 and 97, respectively (C. J. Beer, unpublished data, 2009). The minimum recorded relative abundance of $G$. ruber is $1.5 \%$, occurring during MIS 100. These relatively high abundances even during full glacial conditions show that the ecological 
Table 1. Average Glacial and Interglacial Values of the Variance and Standard Deviation of Raw and Filtered High-Resolution Climate Proxies During Marine Isotope Stages 95 to $103^{\mathrm{a}}$

\begin{tabular}{|c|c|c|c|c|c|c|c|c|c|c|c|c|c|c|}
\hline LR04 Age & MIS & $\begin{array}{c}\text { Linear } \\
\text { Sedimentation } \\
\text { Rate } \\
(\mathrm{cm} / \mathrm{kyr})\end{array}$ & $\begin{array}{c}\text { Variance } \\
L^{*}\end{array}$ & $\begin{array}{l}\text { SD } \\
\mathrm{L}^{*}\end{array}$ & $\begin{array}{l}\text { Variance } \\
\delta^{13} \mathrm{C} \\
\text { G. ruber }\end{array}$ & $\begin{array}{l}\text { SD } \delta^{13} \mathrm{C} \\
\text { G. ruber }\end{array}$ & $\begin{array}{c}\text { Variance } \\
\delta^{18} \mathrm{O} \\
\text { G. ruber }\end{array}$ & $\begin{array}{l}\text { SD } \delta^{18} \mathrm{O} \\
\text { G. ruber }\end{array}$ & $\begin{array}{c}\text { Variance } \\
\text { L* } \\
\text { Filtered }\end{array}$ & $\begin{array}{l}\text { SD L* } \\
\text { Filtered }\end{array}$ & $\begin{array}{l}\text { Variance } \\
\delta^{13} \mathrm{C} \\
\text { G. ruber } \\
\text { Filtered }\end{array}$ & $\begin{array}{c}\text { SD } \\
\delta^{13} \mathrm{C} \\
\text { G. ruber } \\
\text { Filtered }\end{array}$ & $\begin{array}{l}\text { Variance } \\
\delta^{18} \mathrm{O} \\
\text { G. ruber } \\
\text { Filtered }\end{array}$ & $\begin{array}{c}\text { SD } \\
\delta^{18} \mathrm{O} \\
\text { G. ruber } \\
\text { Filtered }\end{array}$ \\
\hline 1.33 & 95 & 5 & 5.899 & 5.089 & 0.034 & 0.184 & 0.014 & 0.117 & 6.17 & 48 & 0.011 & 0.104 & 0.006 & 0.075 \\
\hline 2442.37 & 96 & 5.18 & 10 & 2.665 & 0.014 & .119 & 0.015 & 0. & 3.055 & 1. & 0. & 0.083 & 06 & 0.076 \\
\hline 2466.84 & 97 & 5.93 & 9.993 & 3.161 & 0.053 & 1 & 0.021 & 0.1 & 0.874 & 0. & & 0.079 & & 0.064 \\
\hline 2486 & 98 & 4.51 & 18.532 & 4.305 & 0.035 & & 0.034 & 86 & 4.951 & 2.225 & & 0.086 & & 0.123 \\
\hline 9 & 99 & 5 & .526 & 4.850 & 0. & & 0. & & 4.1 & & & 0.089 & 07 & 0.086 \\
\hline 2525.73 & 100 & 4.32 & 14.808 & 3.848 & 0.052 & 29 & 0.016 & 28 & 2.990 & 1.729 & 0.011 & 0.107 & 0.007 & 0.082 \\
\hline 2547.85 & 101 & 4.99 & 7.538 & 2.745 & 0.043 & 208 & 0.017 & 0.132 & 1.205 & 1.098 & 0.003 & 0.055 & 0.002 & 0.046 \\
\hline 2566.32 & 102 & 5.94 & 3.683 & 1.919 & 0.020 & 0.142 & 0.011 & 0.106 & 1.684 & 1.298 & 0.004 & 0.062 & 0.004 & 0.062 \\
\hline 2583.79 & 103 & 4.56 & 9.462 & 3.076 & 0.007 & 0.085 & 0.010 & 0.102 & 2.674 & 1.635 & 0.003 & 0.053 & 0.003 & 0.057 \\
\hline & & 4. & & 3.184 & & & & & & & & 0.085 & & 0.086 \\
\hline Average IG & & 5.24 & 15.283 & 3.784 & 0.043 & 0.198 & 0.017 & 0.130 & 3.014 & 1.638 & 0.006 & 0.076 & 0.005 & 0.066 \\
\hline
\end{tabular}

${ }^{\mathrm{a}} \mathrm{G}$, glacial; IG, interglacial; SD, standard deviation; MIS, marine oxygen isotope stages. All data are tuned to the LR04 age model [Lisiecki and Raymo, 2005]. The criteria by which G and IG intervals were determined are outlined in section 3.5. Records were notch-filtered at a frequency of 0.025 and a bandwidth of 0.07 to remove the dominant obliquity frequencies.

boundaries of $G$. ruber were likely not crossed. Furthermore, alkenone-based SST records, which are independent of calcification temperature, indicate that (mean annual) SSTs at Site U1313 do not fall below $15^{\circ} \mathrm{C}$ during MIS 98 and 96, and not below $13^{\circ} \mathrm{C}$ during MIS 100 [Naafs et al., 2010; D. Naafs, personal communication, 2010], consistent with the inference that $G$. ruber was living within its ecological tolerances during these glacials. Additionally, we note that largeamplitude G-IG and suborbital variability is recorded in G. ruber $\delta^{18} \mathrm{O}_{\mathrm{pl}}$ during the cooler Pleistocene glacials despite a potential warm calcification bias by G. ruber [Weirauch et al., 2008]. Evidence from a more northern site using different planktic foraminiferal species [Bartoli et al., 2006] corroborates our interpretation that suborbital variability was of small amplitude during the late Pliocene. Thus, our favored interpretation is that the small amplitude in our $\delta^{18} \mathrm{O}_{\mathrm{pl}}$ record is also unlikely to be primarily a function of species choice.

\subsection{Interpreting $\delta^{18} \mathrm{O}_{\mathrm{pl}}$ in Terms of Environmental Variability}

[29] The large amplitude change in $\delta^{18} \mathrm{O}_{\mathrm{pl}}$ observed in the high latitude North Atlantic during the late Pleistocene is a function of the potentially competing influences on the oxygen isotopic composition of surface waters of (1) global sea level, e.g., as best observed during MIS 3 [Siddall et al., 2003], (2) SSTs [Maslin et al., 1995; McManus et al., 1999], and (3) hydrographic change resulting from the addition of meltwater with a highly negative $\delta^{18} \mathrm{O}$ signature from ice sheets and drifting icebergs [Bond et al., 1992] as well as meridional overturning circulation (MOC)-driven salinity oscillations [Weirauch et al., 2008]. In this regard, large additions of meltwater from drifting icebergs $\left(\delta^{18} \mathrm{O}=-20\right.$ to $-30 \%$ VSMOW) have the potential to reduce the amplitude of variability recorded in $\delta^{18} \mathrm{O}_{\mathrm{pl}}$ if maximum iceberg melting (which decreases $\delta^{18} \mathrm{O}_{\mathrm{pl}}$ ) coincides with stadial event cooling (which increases $\delta^{18} \mathrm{O}_{\mathrm{pl}}$ ) [McManus et al., 1999]. However, at Site U1313, extremely low IRD fluxes can be inferred from our IRD record (Figure 3), as evidenced from the very low coarse lithic concentrations in comparison to sites further north, despite similar sedimentation rates [Flesche Kleiven et al., 2002; Becker et al., 2006; Bailey et al., 2010]. Hence, we conclude that it is unlikely that episodes of negative meltwater input during glacials are responsible for the relatively reduced amplitude of suborbital variability in $\delta^{18} \mathrm{O}_{\mathrm{pl}}$ relative to that recorded in late Pleistocene records.

[30] While we can reasonably exclude a detectable contribution to the $\delta^{18} \mathrm{O}_{\mathrm{pl}}$ signal from meltwater at Site U1313, it is difficult, in the absence of independent suborbital SST and eustatic sea level records, to tease apart the influence of local salinity anomalies associated with a strengthening or weakening of MOC versus SST anomalies. Nevertheless, large amplitude shifts in $\delta^{18} \mathrm{O}_{\mathrm{pl}}$ occur during the Pleistocene at Site U1313 (A. Voelker, personal communication, 2010) as well as at other sites outside the IRD belt [de Abreu et al., 2003; Weirauch et al., 2008]. Assuming that the phasing of potentially competing influences on $\delta^{18} \mathrm{O}_{\mathrm{pl}}$ has operated consistently throughout the Plio-Pleistocene at our site, it is unlikely that large-scale eustatic sea level, SST or salinity changes on millennial timescales could have occurred without being expressed in our $\delta^{18} \mathrm{O}_{\mathrm{pl}}$ record.

\subsection{Relationship Between Late Pliocene Suborbital Variability and Sea Level}

[31] The small amplitude changes seen in our $\delta^{18} \mathrm{O}_{\mathrm{pl}}$ record at Site U1313 are comparable to the only other published broadly contemporaneous subpolar North Atlantic $\delta^{18} \mathrm{O}_{\mathrm{pl}}$ record (during MIS 104, 2610 ka) from ODP Site 984 $\left(61^{\circ} \mathrm{N}\right)$ [Bartoli et al., 2006]. Given the more northerly location of Site 984 (Figure 1), we cannot exclude the possibility that the amplitude of $\delta^{18} \mathrm{O}$ variability in surface waters at this site could have been muted by meltwater inputs during stadial events as described in section 5.4. Nevertheless, $\mathrm{Mg} / \mathrm{Ca}$ derived SSTs at this site indicate that suborbital temperature variability during MIS 104 was no greater than $\sim 3^{\circ} \mathrm{C}$ [Bartoli et al., 2006], significantly smaller than SST variability observed in this region during the late Pleistocene [McManus et al., 1999; de Abreu et al., 2003; Naafs et al., 2009; Stein et al., 2009]. Other than at Site U1313 (and its predecessor Site 607), no continuous suborbital-resolution 
$\delta^{18} \mathrm{O}_{\mathrm{pl}}$ records from the subpolar North Atlantic have been published for MIS 103-95, making it difficult to exclude the possibility that large-amplitude surface water variability may have occurred further north during the large glacials MIS 100, 98 and 96. This gap in our knowledge emphasizes the unique contribution of our data set to this debate and strongly highlights the need to recover additional continuously cored sections from more northerly locations.

[32] Estimates of glacial sea level lowstands during our study interval cover a large range. Using a nonlinear transfer function between sea level and Pacific benthic foraminiferal $\delta^{18} \mathrm{O}$ for the late Pleistocene, Siddall et al. [2010] estimated comparatively modest sea level lowstands of $-4 \mathrm{~m}$ (estimate range: -8 to $-1 \mathrm{~m}),-17 \mathrm{~m}$ (range: -35 to $-10 \mathrm{~m}$ ), $-21 \mathrm{~m}$ (range: -42 to $-12 \mathrm{~m}$ ) and $-14 \mathrm{~m}$ (range -20 to $-5 \mathrm{~m}$ ) for MIS 102, 100, 98 and 96, respectively. Inverse forward modeling of sea level change from the LR04 stack estimates lowstands of $-4 \pm 8 \mathrm{~m}$ (MIS 102) and -60 to $-70 \pm 8 \mathrm{~m}$ (MIS 100 , 98 and 96) [Bintanja and van de Wal, 2008; Lourens et al., 2010]. These larger estimates are comparable to those inferred from benthic $\delta^{18} \mathrm{O}$, which are in the range -60 to $-70 \pm 14 \mathrm{~m}$ for MIS 100, 98 and 96 [Miller et al., 2005]. Sea level fluctuations calculated from combined ostracode $\mathrm{Mg} / \mathrm{Ca}$ ratios and benthic foraminiferal $\delta^{18} \mathrm{O}$ also produce estimates of -60 to $-70 \mathrm{~m}$ (MIS 100, 98 and 96) [Dwyer et al., 1995], whereas sea level estimates based on combined benthic foraminferal $\mathrm{Mg} / \mathrm{Ca}$ and $\delta^{18} \mathrm{O}$ data fall in the range -60 to $-100 \pm 32 \mathrm{~m}$ (MIS 100, 98 and 96) [Sosdian and Rosenthal, 2009]. Based on continental margin stratigraphic sequences, sea level fluctuations of -50 to $-60 \mathrm{~m}$ (2.7 to $2.3 \mathrm{Ma})$ [Cronin et al., 1994], and up to $-110 \pm 20 \mathrm{~m}$ (MIS 100) [Naish, 1997; Naish and Wilson, 2009] have been inferred.

[33] We note that a number of these sea level estimates for MIS 100, 98 and 96 suggest that ice volume during these glacials surpassed that associated with large-amplitude suborbital change during the late Pleistocene, yet no significant amplification of high-frequency variability in surface water proxies at Site U1313 is observed. This observation suggests one or both of the following. (1) The threshold value for amplification is not crossed during MIS 100, 98 or 96; indicating that the upper-end estimates of late Pliocene glacial sea level lowstands may be unrealistic. This is consistent with the recent suggestion that the onset of late Pliocene ice-rafting events is associated with a lower ice volume threshold than in the late Pleistocene [Bailey et al., 2010]. (2) Factor(s) other than continental ice volume control the amplification of millennial-scale climate variability (as also highlighted by McManus et al. [1999]). For example, it has been shown that the rate, location or even depth of meltwater injection may be critical in initiating positive climate system feedbacks [Stanford et al., 2006].

[34] The amplitude of millennial-scale variability observed in our records in MIS 102 versus MIS 100, 98, and 96 is similar despite very different estimates of sea level for these glacials ( $-4 \mathrm{~m}$ versus $-60-70 \mathrm{~m})$. Hence, on the basis of our data, it appears that the amplitude of millennial-scale climate variability does not increase linearly over the range of sea level fall associated with our study interval. In this regard, our data are consistent with the idea that subpolar North Atlantic millennial-scale climate exhibits threshold behavior
[McManus et al., 1999; Schulz, 2002]. Interestingly, this observation appears to contrast with evidence from elsewhere [Bartoli et al., 2006], which indicates that the occurrence and amplitude of millennial-scale variability increases progressively during iNHG (3.1 to $2.5 \mathrm{Ma}$ ). Although our study interval does not cover glacial periods prior to MIS 102, the range of sea level change inferred for MIS 103-95 encompasses that of orbital timescale sea level falls for potentially important tipping points in climate instability during the late Pliocene iNHG i.e., MIS G6 (2.75 Ma) [Haug et al., 2005; Bartoli et al., 2006; Sarnthein et al., 2009]. New subpolar North Atlantic records are needed to test these differing hypotheses.

\section{Summary and Conclusions}

[35] High-resolution late Pliocene $\delta^{18} \mathrm{O}_{\mathrm{pl}}, \delta^{13} \mathrm{C}_{\mathrm{pl}}$ and $\mathrm{L}^{*}$ records from Site U1313 in the subpolar North Atlantic clearly display variability at the suborbital scale. We apply a number of different methods to the quantification of the significance of this suborbital climate variability. Spectral analyses reveal a number of significant $(>99 \% \mathrm{CL}$ ) suborbital periodicities between $\sim 1.8$ to $6.2 \mathrm{kyr}$ in both filtered and unfiltered records of $\delta^{18} \mathrm{O}_{\mathrm{pl}}, \delta^{13} \mathrm{C}_{\mathrm{pl}}$ and $\mathrm{L}^{*}$. Wavelet analysis of filtered $\delta^{18} \mathrm{O}_{\mathrm{pl}}, \delta^{13} \mathrm{C}_{\mathrm{pl}}$ and $\mathrm{L}^{*}$ records illustrate that significant $(>95 \% \mathrm{CL})$ suborbital periods are not limited to glacial climates, corroborated by calculations of average variance and standard deviation in each $\mathrm{G} / \mathrm{IG}$ interval. Application of SiZer, a technique that assesses the statistical significance of features in a smoothed record, did not result in the detection of significant suborbital-scale events either in our Site U1313 $\delta^{18} \mathrm{O}_{\mathrm{pl}}$ record or in two Pleistocene $\delta^{18} \mathrm{O}_{\mathrm{pl}}$ records containing large-amplitude suborbital-scale variability. This result is primarily attributable to the sedimentation rates (and therefore time resolution) of these records, which are rarely great enough for the statistical significance of millennial-scale events to be proved beyond doubt. Our results also illustrate the potential problems encountered during the analysis of suborbital-scale climate variability in deeper time, where the absence of large ice sheets (i.e., $>-100$ $\mathrm{m}$ sea level equivalent relative to modern) means that the amplitude of suborbital variability is generally small.

[36] Millennial-scale oscillations in surface water proxies at IODP Site U1313 persist with relatively small amplitude regardless of glacial state and inferred sea level in the range $\sim 0$ to $70 \pm 8 \mathrm{~m}$ below present sea level. Our new Site U1313 data suggest that little or no amplification of suborbital-scale variability within the boundary conditions of late Pliocene $G$ and IG climates occurred. Our findings are consistent with the recent suggestion that a more appropriate tipping point for the amplification of millennial-scale climate change is the MPT [Weirauch et al., 2008]. Available data indicate that no significant large amplification of millennial-scale signals was produced by G-IG ice volume variations associated with either the large-amplitude Pliocene glacials MIS 100, 98 and 96 (this study; Becker et al. [2006]) or the pre-MPT PlioPleistocene glacials [Larrasoaña et al., 2003; Weirauch et al., 2008]. Thus, it appears that ice sheet volume equivalent to that attained by the MPT and the onset of large-amplitude 100 kyr G-IG cycles $(>100 \mathrm{~m}$ estimated sea level equivalent 
[Bintanja and van de Wal, 2008; Rohling et al., 2009]) is required to amplify millennial-scale climate variations to the proportions observed in late Pleistocene North Atlantic records [Bond et al., 1993; Oppo et al., 1998; McManus et al., 1999; Weirauch et al., 2008].

[37] Acknowledgments. This work used samples provided by the Integrated Ocean Drilling Program (IODP). The IODP is sponsored by the U.S. National Science Foundation and participating countries under management of the Joint Oceanographic Institutions (JOI), Inc. We thank the shipboard party of IODP Expeditions 303 and 306 and A. Wuelbers and W. Hale for their help during sampling at Bremen Core Repository. We are grateful to Mike Bolshaw, Dave Spanner, and Tom Hindson for help in the laboratory and Eelco Rohling and Heiko Pälike for useful discussions. Financial support was provided by the Natural Environmental Research Council, NERC, in the form of a Ph.D. studentship to C.T.B. (reference NER/S/A/2006/14218) and a UK IODP grant to P.A.W., R.S., and I.B. I.B. is grateful to UK IODP for financial support for shipboard and postcruise participation in IODP Expedition 306. This study was also partly funded by the European Commission while O.F. held a Marie Curie IntraEuropean Fellowship at the University of Southampton (project PLIO-CLIMATE). We thank Tom Cronin and an anonymous reviewer for comments and suggestions that significantly improved the manuscript.

\section{References}

Alley, R. B., P. U. Clark, L. D. Keigwin, and R. S. Webb (1999), Making sense of millennialscale climate change, in Mechanisms of Global Climate Change at Millennial Time Scales, Geophys. Monogr. Ser., vol. 112, edited by P. U. Clark, R. S. Webb, and L. D. Keigwin, pp. 385-394, AGU, Washington, D. C.

Anderson, D. M. (2001), Attenuation of millennialscale events by bioturbation in marine sediments, Paleoceanography, 16(4), 352-357, doi:10.1029/2000PA000530.

Bailey, I., C. T. Bolton, R. M. DeConto, D. Pollard, R. Schiebel, and P. A. Wilson (2010), A low threshold for North Atlantic ice rafting from "low-slung slippery" late Pliocene ice sheets, Paleoceanography, 25, PA1212, doi:10.1029/ 2009PA001736.

Bartoli, G., M. Sarnthein, and M. Weinelt (2006), Late Pliocene millennial-scale climate variability in the northern North Atlantic prior to and after the onset of Northern Hemisphere glaciation, Paleoceanography, 21, PA4205, doi:10.1029/2005PA001185.

Becker, J. (2005), Late Pliocene millennial to Milankovitch-scale climate variability: A case study of Marine Isotope Stages 101-95 in the Mediterranean and adjacent North Atlantic, dissertation, 164 pp., Utrecht Univ., Utrecht, Netherlands.

Becker, J., L. J. Lourens, F. J. Hilgen, E. van der Laan, T. J. Kouwenhoven, and G.-J. Reichart (2005), Late Pliocene climate variability on Milankovitch to millennial time scales: A high-resolution study of MIS 100 from the Mediterranean, Palaeogeogr. Palaeoclimatol. Palaeoecol., 228, 338-360, doi:10.1016/j. palaeo.2005.06.020

Becker, J., L. J. Lourens, and M. E. Raymo (2006), High-frequency climate linkages between the North Atlantic and the Mediterranean during marine oxygen isotope stage 100 (MIS100), Paleoceanography, 21, PA3002, doi:10.1029/2005PA001168.

Bijma, J., W. W. Faber, and C. Hemleben (1990), Temperature and salinity limits for growth and survival of some planktonic foraminfers in laboratory cultures, J. Foraminiferal Res., 20, 95-116, doi:10.2113/gsjfr.20.2.95.

Bintanja, R., and R. S. W. van de Wal (2008), North American ice-sheet dynamics and the onset of 100,000-year glacial cycles, Nature, 454, 869-872, doi:10.1038/nature07158.

Blum, P. (1997), Reflectance spectrophotometry and colorimetry, in Physical Properties Handbook, edited by P. Blum, chap. 7, pp. 7-1-7-11, Ocean Drill. Program, College Station, Tex.

Bond, G., and R. Lotti (1995), Iceberg discharges into the North Atlantic on millennial time scales during the last glaciation, Science,
267(5200), 1005-1010, doi:10.1126/science. 267.5200 .1005 .

Bond, G., et al. (1992), Evidence for massive discharges of icebergs into the North Atlantic ocean during the last glacial period, Nature, 360, 245-249, doi:10.1038/360245a0.

Bond, G. C., W. S. Broecker, S. Johnsen, J. F McManus, L. Labeyrie, J. Jouzel, and G. Bonan (1993), Correlation between climate records from North Atlantic sediments and Greenland ice, Nature, 365, 143-147, doi:10.1038/ $365143 \mathrm{a} 0$.

Bond, G., W. Showers, M. Cheseby, R. Lotti, P. Almasi, P. deMenocal, P. Priore, H. Cullen, I. Hajdas, and G. Bonani (1997), A pervasive millennial-scale cycle in North Atlantic Holocene and glacial climates, Science, 278, 12571266, doi:10.1126/science.278.5341.1257.

Bond, G. C., W. Showers, M. Elliot, M. Evans, R. Lotti, I. Hajdas, G. Bonani, and S. Johnson (1999). The North Atlantic's 1-2 kyr climate rhythm: Relation to Heinrich events, Dansgaard-Oeschger cycles and the little ice age, in Mechanisms of Global Change at Millennial Time Scales, Geophys. Monogr. Ser., vol. 112, edited by P. U. Clark, R. S. Webb, and L. D. Keigwin, pp. 59-76, AGU, Washington, D. C.

Broecker, W. (1997), Thermohaline circulation, the Achilles heel of our climate system: Will man-made $\mathrm{CO}_{2}$ upset the current balance?, Science, 278, 1582-1588, doi:10.1126/science. 278.5343.1582

Broecker, W., G. Bond, M. Klas, E. Clark, and J. McManus (1992), Origin of the northern Atlantic's Heinrich events, Clim. Dyn., 6, 265-273, doi:10.1007/BF00193540.

Calvo, E., J. Villanueva, J. O. Grimalt, A. Boelaert, and L. Labeyrie (2001), New insights into the glacial latitudinal temperature gradients in the North Atlantic. Results from $\mathrm{U}_{37}^{\mathrm{K}^{\prime}}$ sea surface temperatures and terrigenous inputs, Earth Planet. Sci. Lett., 188, 509-519, doi:10.1016/ S0012-821X(01)00316-8.

Channell, J. E. T., C. Xuan, and D. A. Hodell (2009), Stacking paleointensity and oxygen isotope data for the last 1.5 Myr (PISO-1500), Earth Planet. Sci. Lett., 283, 14-23, doi:10.1016/j.eps1.2009.03.012. Chaudhuri, P., and J. S. Marron (1999), SiZer for exploration of structures in curves, J. Am. Stat. Soc., 94, 807-823.

Clark, P. U., R. B. Alley, and D. Pollard (1999), Northern Hemisphere ice-sheet influences on global climate change, Science, 286, 11041111, doi:10.1126/science.286.5442.1104.

Clement, A. C., and L. C. Peterson (2008), Mechanisms of abrupt climate change of the last glacial period, Rev. Geophys., 46, RG4002, doi:10.1029/2006RG000204.
Cronin, T. M., A. Kitamura, N. Ikeya, M. Watanabe, and T. Kamiya (1994), Late Pliocene climate change 3.4-2.3 Ma: Paleoceanographic record from the Yabuta Formation, Sea of Japan, Palaeogeogr. Palaeoclimatol. Palaeoecol. 108, 437-455, doi:10.1016/0031-0182(94) 90245-3.

Dansgaard, W., et al. (1993), Evidence for general instability of past climate from a 250-kyr icecore record, Nature, 364(6434), 218-220, doi: $10.1038 / 364218 \mathrm{a} 0$.

de Abreu, L., N. J. Shackleton, J. Schönfeld, M. A. Hall, and M. Chapman (2003), Millennial scale oceanic climate variability off the western Iberian margin during the last two glacial periods, Mar. Geol., 196, 1-20, doi:10.1016/S0025-3227(03)00046-X.

Draut, A. E., M. E. Raymo, J. F. McManus, and D. W. Oppo (2003), Climate stability during the Pliocene warm period, Paleoceanography, 18(4), 1078, doi:10.1029/2003PA000889.

Dwyer, G. S., T. M. Cronin, P. A. Baker, M. E Raymo, J. S. Buzas, and T. Correge (1995), North Atlantic deepwater temperature change during late Pliocene and late Quaternary climatic cycles, Science, 270, 1347-1351, doi: $10.1126 /$ science. 270.5240 .1347 .

Expedition 306 Scientists (2006), Site U1313, in North Atlantic Climate, Proc. Integr. Ocean Drill. Program, 303/306, doi:10.2204/iodp proc.303306.112.2006.

Flesche Kleiven, H., E. Jansen, T. Fronval, and T. M. Smith (2002), Intensification of Northern hemisphere glaciations in the circum Atlantic region (3.5-2.4 Ma)-Ice-rafted detritus evidence, Palaeogeogr. Palaeoclimatol. Palaeoecol., 184, 213-223, doi:10.1016 S0031-0182(01)00407-2.

Ganopolski, A., and S. Rahmstorf (2001), Rapid changes of glacial climate simulated in a coupled climate model, Nature, 409, 153-158, doi: $10.1038 / 35051500$.

Ghil, M., et al. (2002), Advanced spectral methods for climatic time series, Rev. Geophys., 40(1), 1003, doi:10.1029/2000RG000092.

Grootes, P. M., M. Stuiver, J. W. C. White, S. Johnsen, and J. Jouzel (1993), Comparison of oxygen isotope records from the GISP2 and GRIP Greenland ice cores, Nature, 366(6455), 552-554, doi:10.1038/366552a0.

Haug, G. H., et al. (2005), North Pacific seasonality and the glaciation of North America 2.7 million years ago, Nature, 433, 821-825, doi:10.1038/nature03332.

Heinrich, H. (1988), Origin and consequences of cyclic ice rafting in the northeast Atlantic Ocean during the past 130,000 years, Quat. Res., 29, 142-152, doi:10.1016/0033-5894 (88)90057-9. 
Hemming, S. R. (2004), Heinrich events: Massive late Pleistocene detritus layers of the North Atlantic and their global climate imprint, Rev. Geophys., 42, RG1005, doi:10.1029/ 2003RG000128.

Jansen, E., T. Fronval, F. Rack, and J. E. T. Channell (2000), Pliocene-Pleistocene ice rafting history and cyclicity in the Nordic Seas during the last $3.5 \mathrm{Myr}$, Paleoceanography, 15(6), 709-721, doi:10.1029/1999PA000435.

Johnsen, S. J., H. B. Clausen, W. Dansgaard, K. Fuhrer, N. Gundestrup, C. U. Hammer, P. Iversen, J. Jouzel, B. Stauffer, and J. P. Steffensen (1992), Irregular glacial interstadials recorded in a new Greenland ice core, Nature, 359, 311-313, doi:10.1038/359311a0.

Keigwin, L. D., and T. P. Guilderson (2009), Bioturbation artifacts in zero-age sediments, Paleoceanography, 24, PA4212, doi:10.1029/ 2008PA001727.

Knutti, R., J. Fluckiger, T. F. Stocker, and A. Timmerman (2004), Strong hemispheric coupling of glacial climate through freshwater discharge and ocean circulation, Nature, 430, 851-856, doi:10.1038/nature02786.

Langway, C. C., Jr., H. Oeschger, and W. Dansgaard (Eds.) (1985), Greenland Ice Core: Geophysics, Geochemistry, and the Environment, Geophys. Monogr. Ser., vol. 33, 118 pp., AGU, Washington, D. C

Larrasoaña, J. C., A. P. Roberts, E. J. Rohling, M. Winklhofer, and R. Wehausen (2003), Three million years of monsoon variability over the northern Sahara, Clim. Dyn., 21, 689-698, doi:10.1007/s00382-003-0355-z.

Lisiecki, L. E., and M. E. Raymo (2005), A Pliocene-Pleistocene stack of 57 globally distributed benthic $\delta^{18} \mathrm{O}$ records, Paleoceanography, 20, PA1003, doi:10.1029/2004PA001071.

Lourens, L. J., R. Wehausen, and H. J. Brumsack (2001), Geological constraints on tidal dissipation and dynamical ellipticity of the Earth over the past three million years, Nature, 409, 1029-1033, doi:10.1038/35059062.

Lourens, L. J., J. Becker, R. Bintanja, F. J. Hilgen, E. Tuenter, R. S. W. van de Wal, and M. Ziegler (2010), Linear and non-linear response of late Neogene glacial cycles to obliquity forcing and implications for the Milankovitch theory, Ouat. Sci. Rev., 29, 352-365, doi:10.1016/j.quascirev.2009.10.018.

Marshall, S. J., and M. R. Koutnik (2006), Ice sheet action versus reaction: Distinguishing between Heinrich events and DansgaardOeschger cycles in the North Atlantic, Paleoceanography, 21, PA2021, doi:10.1029/ 2005PA001247

Maslin, M. A., N. J. Shackleton, and U. Pflaumann (1995), Surface water temperature, salinity, and density changes in the northeast Atlantic during the last 45,000 years: Heinrich events, deep water formation, and climatic rebounds, Paleoceanography, 10(3), 527-544, doi:10.1029/ 94PA03040.

Mc Intyre, K., M. L. Delaney, and A. C. Ravelo (2001), Millennial-scale climate change and oceanic processes in the late Pliocene and early Pleistocene, Paleoceanography, 16, 535-543, doi:10.1029/2000PA000526.

McManus, J., D. W. Oppo, and J. L. Cullen (1999), A 0.5-million-year record of millennialscale climate variability in the North Atlantic, Science, 283, 971-975, doi:10.1126/science. 283.5404.971
Meyers, S. R., and L. A. Hinnov (2010), Northern Hemisphere glaciation and the evolution of Plio-Pleistocene climate noise, Paleoceanography, 25, PA3207, doi:10.1029/ 2009PA001834.

Miller, K. G., M. A. Kominz, J. V. Browning, J. D. Wright, G. S. Mountain, M. E. Katz, P. J. Sugarman, B. S. Cramer, N. ChristieBlick, and S. F. Pekar (2005), The Phanerozoic record of global sea-level change, Science, 310, 1293-1298, doi:10.1126/science.1116412

Naafs, B. D. A., R. Stein, and G. H. Haug (2009), Pliocene climate and Northern Hemisphere Glaciation as seen from the North Atlantic, paper presented at Workshop on Pliocene Climate, Eur. Sci. Found., Bordeaux, France.

Naafs, B. D. A., R. Stein, J. Hefter, N. Khélifi, S. De Schepper, and G. H. Haug (2010), Late Pliocene changes in the North Atlantic Current, Earth Planet. Sci. Lett., doi:10.1016/j. eps1.2010.08.023.

Naish, T. (1997), Constraints on the amplitude of late Pliocene eustatic sea-level fluctuations: New evidence from the New Zealand shallowmarine sediment record, Geology, 25(12) 1139-1142, doi:10.1130/0091-7613(1997) 025<1139:COTAOL $>2.3 . \mathrm{CO} ; 2$.

Naish, T., and G. S. Wilson (2009), Constraints on the amplitude of Mid-Pliocene (3.6-2.4 Ma) eustatic sea level fluctuations from the New Zealand shallow-marine sediment record, Philos. Trans. R. Soc., Ser. A, 367, 169-187, doi:10.1098/rsta.2008.0223.

Oppo, D. W., and S. J. Lehman (1995), Suborbital timescale variability of North Atlantic Deep Water during the past 200,000 years, $\mathrm{Pa}$ leoceanography, 10(5), 901-910, doi:10.1029/ 95PA02089.

Oppo, D. W., J. F. McManus, and J. L. Cullen (1998), Abrupt climate events 500,000 to 340,000 years ago: Evidence from subpolar North Atlantic, Science, 279, 1335-1338, doi:10.1126/science. 279.5355.1335.

Oppo, D. W., L. D. Keigwin, J. McManus, and J. L. Cullen (2001), Persistent suborbital climate variability in marine isotope stage 5 and Termination II, Paleoceanography, 16(3), 280-292, doi:10.1029/2000PA000527.

Ortiz, J., A. Mix, S. Harris, and S. O'Connell (1999), Diffuse spectral reflectance as a proxy for percent carbonate content in North Atlantic sediments, Paleoceanography, 14(2), 171 186, doi:10.1029/1998PA900021.

Paillard, D., L. Labeyrie, and P. Yiou (1996), Macintosh program performs time-series analysis, Eos Trans. $A G U, 77,379$, doi:10.1029/ 96EO00259.

Rahmstorf, S. (2003), Timing of abrupt climate change: A precise clock, Geophys. Res. Lett. 30(10), 1510, doi:10.1029/2003GL017115.

Raymo, M. E., W. F. Ruddiman, J. Backman, A. C. Clement, and D. G. Martinson (1989), Late Pliocene variation in Northern Hemisphere ice sheets and North Atlantic deepwater circulation, Paleoceanography, 4(4), 413-446, doi:10.1029/PA004i004p00413.

Raymo, M. E., D. A. Hodell, and E. Jansen (1992), Response of deep ocean circulation to initiation of Northern Hemisphere glaciation (3-2 Ma), Paleoceanography, 7, 645-672, doi:10.1029/92PA01609.

Raymo, M. E., K. Ganley, S. Carter, D. W. Oppo, and J. McManus (1998), Millennial-scale climate instability during the early Pleistocene epoch, Nature, 392, 699-702, doi:10.1038/ 33658.

Rohling, E. J., and H. Pälike (2005), Centennialscale climate cooling with a sudden cold even around 8,200 years ago, Nature, 434, 975979, doi:10.1038/nature03421

Rohling, E. J., K. Grant, M. Bolshaw, A. P. Roberts, M. Siddall, C. Hemleben, and M. Kucera (2009), Antarctic temperature and global sea level closely coupled over the past five glacial cycles, Nat. Geosci., 2, 500-504, doi:10.1038/ngeo557.

Ruddiman, W. F. (1977a), North Atlantic icerafting: A major change at 75,000 years before the present, Science, 196, 1208-1211, doi:10.1126/science.196.4295.1208.

Ruddiman, W. F. (1977b), Late Quaternary deposition of ice-rafted sand in the subpolar North Atlantic (lat $40^{\prime}$ to $65^{\prime} \mathrm{N}$ ), Geol. Soc. Am. Bull., 88, 1813-1827, doi:10.1130/00167606(1977)88<1813:LQDOIS > 2.0.CO;2.

Ruddiman, W. F., et al. (1987), Initial Reports of the Deep Sea Drilling Project, Govt. Print Off, Washington, D. C.

Ruddiman, W. F., M. E. Raymo, D. G. Martinson, B. M. Clement, and J. Backman (1989), Pleistocene evolution: Northern hemisphere ice sheets and North Atlantic Ocean, Paleoceanography, 4(4), 353-412, doi:10.1029/ PA004i004p00353.

Sarnthein, M., G. Bartoli, M. Prange, A. Schmittner, B. Schneider, M. Weinelt, N. Andersen, and D. Garbe-Schonberg (2009), Mid-Pliocene shifts in ocean overturning circulation and the onset of Quaternary-style climates, Clim. Past, 5, 269-283, doi:10.5194/ cp-5-269-2009.

Schmidt, G. A., and S. Mulitza (2002), Global calibration of ecological models for planktic foraminifera from coretop carbonate oxygen18, Mar. Micropaleontol., 44, 125-140, doi:10.1016/S0377-8398(01)00041-X.

Schulz, M. (2002), On the 1470-year pacing of Dansgaard-Oeschger warm events, Paleoceanography, 17(2), 1014, doi:10.1029/ 2000PA000571.

Schulz, M., W. H. Berger, M. Sarnthein, and P. M. Grootes (1999), Amplitude variation of 1470-year climate oscillations during the last 100,000 years linked to fluctuations of continental ice mass, Geophys. Res. Lett., 26(22), 3385-3388, doi:10.1029/1999GL006069.

Shackleton, N. J., and M. A. Hall (1984), Oxygen and carbon isotope stratigraphy of Deep Sea Drilling Project Hole 552A: Plio-Pleistocene glacial history, Initial Rep. Deep Sea Drill. Proj., 81, 599-609.

Shipboard Scientific Party (1987), Site 609, Initial Rep. Deep Sea Drill. Proj., 94, 247-349.

Shipboard Scientific Party (1996), Site 984 Proc. Ocean Drill. Program Initial Rep., 162, 169-222.

Siddall, M., E. J. Rohling, A. Almogi-Labin, C. Hemleben, D. Meischner, I. Schmelzer, and D. A. Smeed (2003), Sea-level fluctuations during the last glacial cycle, Nature, 423, 853-858, doi:10.1038/nature01690.

Siddall, M., B. Hönisch, C. Waelbroeck, and P. Huybers (2010), Changes in deep Pacific temperature during the mid-Pleistocene transition and Quaternary, Quat. Sci. Rev., 29, 170181, doi:10.1016/j.quascirev.2009.05.011.

Sosdian, S., and Y. Rosenthal (2009), Deep-sea temperature and ice volume changes across the Pliocene-Pleistocene climate transitions, 
Science, 325, 306-310, doi:10.1126/science. 1169938.

Stanford, J. D., E. J. Rohling, S. E. Hunter, A. P. Roberts, S. O. Rasmussen, E. Bard, J. McManus, and R. G. Fairbanks (2006), Timing of meltwater pulse $1 \mathrm{a}$ and climate responses to meltwater injections, Paleoceanography, 21, PA4103, doi:10.1029/2006PA001340.

Steenbrink, J., M. L. Kloosterboer-van Hoeve, and F. J. Hilgen (2003), Millennial-scale climate variations recorded in Early Pliocene colour reflectance time series from the lacrustine Ptolemais Basin (NW Greece), Global Planet. Change, 36, 47-75, doi:10.1016/S0921-8181 (02)00163-7.

Stein, R., J. Hefter, J. Grützner, A. Voelker, and B. D. A. Naafs (2009), Variability of surface water characteristics and Heinrich-like events in the Pleistocene midlatitude North Atlantic Ocean: Biomarker and XRD records from IODP Site U1313 (MIS 16-9), Paleoceanography, 24, PA2203, doi:10.1029/ 2008PA001639.

Torrence, C., and G. P. Compo (1998), A practical guide to wavelet analysis, Bull. Am. Meteorol.
Soc., 79(1), 61-78, doi:10.1175/1520-0477 (1998)079<0061:APGTWA>2.0.CO;2.

Voelker, A. H. L., and Workshop Participants (2002), Global distribution of centennial-scale records for Marine Isotope Stage (MIS) 3: A database, Quat. Sci. Rev., 21, 1185-1212, doi:10.1016/S0277-3791(01)00139-1.

Wara, M., A. C. Ravelo, and J. Revenaugh (2000), The pacemaker always rings twice, $P a$ leoceanography, 15, 616-624, doi:10.1029/ 2000PA000500.

Weber, M. E., N. Tougiannidis, M. Kleineder, N. Bertram, W. Ricken, C. Rolf, T. Reinsch, and P. Antoniadis (2010), Lacustrine sediments document millennial-scale climate variability in northern Greece prior to the onset of the northern hemisphere glaciation, Palaeogeogr. Palaeoclimatol. Palaeoecol., 291 360-370, doi:10.1016/j.palaeo.2010.03.007.

Weedon, G. P. (2003), Time-Series Analysis and Cyclostratigraphy, Cambridge Univ. Press, New York, doi:10.1017/CBO9780511535482.

Weirauch, D., K. Billups, and P. Martin (2008), Evolution of millennial-scale climate variabil- ity during the mid-Pleistocene, Paleoceanography, 23, PA3216, doi:10.1029/2007PA001584.

I. Bailey, C. J. Beer, and P. A. Wilson, National Oceanography Centre, Southampton, School of Ocean and Earth Science, University of Southampton, European Way, Southampton SO14 3ZH, UK.

S. Baranwal, Geological Survey of Norway, Leiv Eirikssons vei 39, N-7491 Trondheim, Norway.

J. Becker, School of Ocean and Earth Sciences, University of Cardiff, Main Building, Park Place, Cardiff CF10 3YE, UK.

C. T. Bolton, Department of Geology, University of Oviedo, Arias de Velasco s/n, E-3305 Oviedo, Asturias, Spain. (cbolton@geol.uniovi.es)

O. Friedrich, Facheinheit Paläontologie, Institut für Geowissenschaften, Altenhöferallee 1, D-60438 Frankfurt, Germany.

R. Schiebel, Laboratoire des Bio-Indicateurs Actuels et Fossiles, Université d'Angers 2 Boulevard Lavoisier, F-49045 Angers CEDEX 01, France. 